\title{
The landscape of targeted therapies for cholangiocarcinoma: current status and emerging targets
}

\author{
Dawn Q. Chong ${ }^{1,2}$ and Andrew X. Zhu ${ }^{1}$ \\ ${ }^{1}$ Massachusetts General Hospital Cancer Center, Harvard Medical School, Boston, MA, USA \\ 2 Division of Medical Oncology, National Cancer Centre Singapore, Singapore \\ Correspondence to: Andrew X. Zhu, email: azhu@partners.org \\ Keywords: cholangiocarcinoma, genetics, IDH, FGFR2 \\ Received: December 19,2015 Accepted: April 10, $2016 \quad$ Published: April 18, 2016
}

\section{ABSTRACT}

Cholangiocarcinoma (CCA) is a relatively rare malignancy that arises from the epithelial cells of the intrahepatic, perihilar and distal biliary tree. Intrahepatic CCA (ICC) represents the second most common primary liver cancer, after hepatocellular cancer. Two-thirds of the patients with ICC present with locally advanced or metastatic disease. Despite standard treatment with gemcitabine and cisplatin, prognosis remains dismal with a median survival of less than one year. Several biological plausibilities can account for its poor clinical outcomes. First, despite the advent of next generation and whole exome sequencing, no oncogenic addiction loops have been validated as clinically actionable targets. Second, the anatomical, pathological and molecular heterogeneity, and rarity of CCA confer an ongoing challenge of instituting adequately powered clinical trials. Last, most of the studies were not biomarker-driven, which may undermine the potential benefit of targeted therapy in distinct subpopulations carrying the unique molecular signature. Recent whole genome sequencing efforts have identified known mutations in genes such as epidermal growth factor receptor (EGFR), Kirsten rat sarcoma viral oncogene homolog (KRAS), v-raf murine sarcoma viral oncogene homolog (BRAF) and tumor protein p53 (TP53), novel mutations in isocitrate dehydrogenase (IDH), BRCA1-Associated Protein 1 (BAP1) and AT-rich interactive domain-containing protein 1A (ARID1A), and novel fusions such as fibroblast growth factor receptor 2 (FGFR2) and ROS proto-oncogene 1 (ROS1). In this review, we will discuss the evolving genetic landscape of CCA, with an in depth focus on novel fusions (e.g. FGFR2 and ROS1) and somatic mutations (e.g. IDH1/2), which are promising actionable molecular targets.

\section{INTRODUCTION}

Cholangiocarcinoma (CCA) comprises of malignancy arising from the intrahepatic, perihilar and distal biliary tree. Intrahepatic CCA (ICC) is the second most common primary hepatic malignancy, after hepatocellular carcinoma, and accounts for 10$20 \%$ of primary liver cancers $[1,2]$. The incidence and mortality rates of ICC have been rising worldwide in the past decade, whereas those of extrahepatic CCA (ECC) are either stable or decreasing [2]. In the Western countries, the annual incidence of ICC is 2.1 per 100,000 person years [3]. Chronic inflammation from liver fluke infestation, hepatitis $\mathrm{B}$ and $\mathrm{C}$ infections, primary sclerosing cholangitis and inflammatory bowel disease are the main risk factors of CCA [4]. Other less common etiologic factors include hepatolithiasis, cirrhosis, alcohol, smoking, fatty liver disease and cholelithiasis [1].

Only $10-15 \%$ of the patients with CCA are amenable to potentially curative surgery, as majority present at an advanced stage due to lack of effective screening strategies [5]. Despite resection, high recurrence rates of $50-60 \%$ persist, conferring a five-year overall survival (OS) of only $30 \%[5,6]$. The high rate of relapse prompted a strong rationale for adjuvant therapies to improve survival. However, the available evidence remains conflicting as randomized adjuvant trials are still ongoing. A meta-analysis of 6,712 biliary tract cancer 
(BTC) patients who received varying forms of adjuvant therapy (chemotherapy, radiotherapy, chemoradiotherapy) demonstrated no clear survival benefit with adjuvant treatment (Odds ratio (OR) 0.74, 95\% Confidence interval (CI) $0.55-1.01 ; P=0.06$ ) [7]. Liver transplantation, though not considered as standard therapy for CCA, has also been explored in selected patients with early stage perihilar CCA, where complete resection is impossible due to vascular or biliary invasion. A meta-analysis of $605 \mathrm{CCA}$ patients who underwent liver transplantation demonstrated a 5 -year OS of $39 \%$, with superior outcomes in those who underwent perioperative chemoradiotherapy (5-year OS $57 \%)[8]$.

Majority of the patients present at an advanced stage, with limited treatment options which include locoregional or systemic therapy. There has been a growing interest in various locoregional therapy modalities including transarterial chemoembolization, selective internal radiotherapy, external beam radiation or ablation in patients who present with liver-limited disease [9]. However, these therapies were evaluated in small retrospective series or single arm phase II trials, and thus limit generalizability. The current standard of care for first line treatment of unresectable CCA is the combination of gemcitabine and cisplatin, albeit with modest benefit [10]. The prognosis of patients with unresectable or metastatic CCA is universally poor, with a median OS of less than one year. The treatment complexity is further confounded by the presence of recurrent cholangitis or cholestasis, necessitating interventions for restoration of biliary drainage and long term antibiotics use, thus leading to delays in systemic treatment.

Notably, the conduct of phase III randomized controlled trials (RCTs) have been exceptionally challenging due to the rarity of CCA and its inherent anatomical, pathological and molecular heterogeneity. With the advent of whole genome sequencing, mutations in epidermal growth factor receptor $(E G F R)$, Kirsten rat sarcoma viral oncogene homolog $(K R A S)$, v-raf murine sarcoma viral oncogene homolog $(B R A F)$ and tumor protein p53 (TP53) were unraveled. More recently, novel mutations in isocitrate dehydrogenase $(I D H)$, BRCA1Associated Protein $1(B A P 1)$ and AT-rich interactive domain-containing protein 1A $(A R I D 1 A)$, and novel fusions such as fibroblast growth factor receptor (FGFR2) and ROS proto-oncogene 1 (ROS1) were revealed. In this review, we will discuss the evolving genetic landscape and summarize the targeted therapies in CCA.

\section{SYSTEMIC CHEMOTHERAPY}

The standard of care for first line chemotherapy for advanced CCA is the combination of gemcitabine and cisplatin. The pivotal United Kingdom National Cancer Research Institute Advanced Biliary Cancer (ABC)-02 study reported superior survival with gemcitabine and cisplatin (GC), with a median OS of 11.7 months versus 8.1 months, and median progression free survival (PFS) of 8.0 months versus 5.0 months, when compared to gemcitabine alone [10]. Despite intensified evaluation of other chemotherapy combinations with fluorouracil, oxaliplatin or irinotecan, the improvement in survival has been marginal [11]. Currently, there is no standard secondline chemotherapy. In a systemic review of 761 patients, treatment with second-line chemotherapy attained a mean OS of 7.2 months (95\% CI 6.2-8.2), PFS of 3.2 months (95\% CI 2.7-3.7), response rate (RR) of 7.7\% (95\% CI $6.5-8.9)$ and disease control rate (DCR) of $49.5 \%(95 \%$ CI 41.4-57.7) [12]. However, these results need to be interpreted with caution. First, patients who receive second-line chemotherapy have better performance status, which may be associated with improved prognosis [13]. Second, only $15-25 \%$ of patients will be fit enough to receive second-line treatment [14]. Third, no RCTs have been included in this systemic review. Given the marginal advances with chemotherapy, emphasis has been shifted to molecularly targeted therapies, either as a single agent or in combination with chemotherapy.

\section{CURRENT GENETIC LANDSCAPE}

CCA represents a molecularly diverse subgroup of BTCs. Genomic profiling with whole-exome and nextgeneration sequencing has identified multiple molecular aberrations that contribute to its multistep carcinogenesis [15-17]. Well established genomic alterations include overexpression of EGFR (5\%-27\%), vascular endothelial growth factor (VEGF) and its receptor (VEGFR) (55\%$60 \%$ ), human epidermal growth factor receptor 2 (HER2)/ erb-b2 receptor tyrosine kinase 2 (ERBB2) (0\%-20\%) [15-19], and MET proto-oncogene (MET) (7\%-21\%) [15, $17,19,20]$, mutations in $B R A F(5 \%)$ and loss of function mutation in TP53 (3\%-45\%) [15-17, 21]. Dysregulation of a plethora of key signaling pathways such as $R A S / R A F /$ mitogen-activated extracellular signal regulated kinase $(M E K) /$ extracellular signal-regulated kinases (ERK) and phosphatidylinositol 3-kinase $(P I 3 K) /$ phosphatase and tensin $(P T E N) /$ protein kinase $\mathrm{B}(A K T) /$ mechanistic target of rapamycin $(M T O R)$ further contribute to its malignant transformation [15-17, 21]. The first whole exome sequencing study of 8 liver-fluke related CCA identified 206 somatic mutations in 187 genes, including novel genes (e.g. SMAD4 $(16.7 \%)$, roundabout guidance receptor 2 (ROBO2) (9.3\%), GNAS (9.3\%), MLL3 (14.8\%), Cyclin-dependent kinase inhibitor 2A (CDKN2A) (5.6\%), paternally expressed 3 (PEG3) (5.6\%), ring fingers proteins $(R N F)(9.3 \%)$ [22]. Another study with genomic profiling on 209 CCA revealed that SMAD4 and TP53 were more frequent in Opisthorchis viverrini related $\mathrm{CCA}$, and $I D H 1 / 2$ mutations were more frequent in nonOpisthorchis viverrini related CCA [23]. Furthermore, chromatin remodeling genes such as BAP1, ARID1A, 
Table 1: Molecular aberrations in cholangiocarcinoma

\begin{tabular}{|c|c|c|c|}
\hline & $\begin{array}{l}\text { Intrahepatic } \\
\text { cholangiocarcinoma }\end{array}$ & $\begin{array}{l}\text { Extrahepatic } \\
\text { cholangiocarcinoma }\end{array}$ & Reference \\
\hline EGFR overexpression & $11 \%-27 \%$ & $5 \%-19 \%$ & [15-19] \\
\hline$K R A S$ mutation & $9 \%-24 \%$ & $40 \%$ & [15-17] \\
\hline HER2 overexpression & $0 \%-2 \%$ & $5 \%-20 \%$ & {$[15-19]$} \\
\hline $\begin{array}{l}V E G F \\
\text { overexpression }\end{array}$ & $54 \%$ & $59 \%$ & {$[15-19]$} \\
\hline $\begin{array}{l}\text { PIK3CA mutation or } \\
\text { deletion }\end{array}$ & $4 \%$ & NR & {$[15-19]$} \\
\hline$B R A F$ mutation & $5 \%$ & NR & {$[21]$} \\
\hline MET overexpression & $7 \%-21 \%$ & $0 \%$ & {$[15,17,19]$} \\
\hline IDH1/IDH2 mutation & $16 \%-36 \%$ & $0 \%$ & $\begin{array}{l}{[15-17,21,24-27,} \\
54]\end{array}$ \\
\hline$F G F R$ translocations & $6 \%-50 \%$ & $0-5 \%$ & {$[15-17,28-30,60]$} \\
\hline TP53 mutation & $3 \%-36 \%$ & $45 \%$ & [15-17] \\
\hline ARID1A mutation & $19 \%-36 \%$ & $5 \%$ & {$[16,17,24]$} \\
\hline MCL1 amplification & $16 \%-21 \%$ & NR & {$[16,17]$} \\
\hline PTEN mutation & $1 \%-11 \%$ & NR & {$[15,17,21]$} \\
\hline PBRM1 mutation & $11 \%-17 \%$ & $5 \%$ & {$[16,24]$} \\
\hline BAPl mutation & $9 \%-25 \%$ & $10 \%$ & {$[16,24]$} \\
\hline SMAD4 mutation & $4 \%$ & $25 \%$ & {$[16]$} \\
\hline$F B X W 7$ mutation & $6 \%$ & $15 \%$ & [16] \\
\hline$C D K N 2 A$ mutation & $7 \%$ & $15 \%$ & [17] \\
\hline CDK6 mutation & $7 \%$ & NR & [17] \\
\hline$B R C A$ mutation & $4 \%$ & NR & [17] \\
\hline NF1 mutation & $4 \%$ & NR & {$[17]$} \\
\hline TSC1 deletion & $4 \%$ & \begin{tabular}{|l|} 
NR \\
\end{tabular} & {$[17]$} \\
\hline ROS1 fusion & $8.7 \%$ (all CCA) & NR & {$[15,32]$} \\
\hline
\end{tabular}

Abbreviations: NR, not reported

Protein polybromo-1 (PBRM1), and MLL3 were found to be highly mutated in CCA [24]. Other novel genetic signatures include $I D H$ mutations (16\%-36\%) [15-17, 21, 24-27], FGFR (5\%-50\%) [15-17, 28-31] and ROS1 fusions $(9 \%)[15,32]$. The prevalence of these genetic aberrations vary widely across studies, anatomical sites and geographically, primarily attributed to the heterogeneity of BTCs, limited sample size, retrospective nature of majority of the studies, and different techniques used to identify the genomic mutations.

Next generation sequencing (NGS) of 46 cancerrelated genes in $75 \mathrm{CC}$ patients has highlighted anatomical variability in frequency of mutations [16]. Notably, it may be technically challenging to distinguish ICC and ECC based on pathology, and hence there may be inherent biases in these studies. The common genetic alterations in ICC include TP53 (30\%), KRAS (24\%), ARIDIA (20\%), IDH1 (18\%) and MCL1 (16\%), whereas for extrahepatic CCA, common aberrations include TP53 (45\%), KRAS (40\%), ERBB2 (20\%), SMAD4 (25\%), F-box/WD repeatcontaining protein 7 (FBXW7) (15\%) and CDKN2A
$(15 \%)$. Furthermore, there were significant differences with regards to the prognostic significance of the above molecular markers, with TP53, KRAS and MTOR alterations predicting a worse prognosis in ICC, and $B A P 1, P B R M 1$ and chromatin modulating genes linked to a worse survival in ECC. A subsequent meta-analysis of 4,458 patients with the study of 102 individual markers revealed that genetic alterations of $H E R 2$ and TP53 were more common in ECC, and BCL-2, EGFR, SMAD4, $p 16$ and $V E G F-A$ were more frequent in ICC [33]. Table 1 summarizes the molecular aberrations in CCA. In the following section, we will highlight the known molecular aberrations in conjunction with their targeted therapies. Figure 1 depicts the key signaling pathways in the pathogenesis of CCA, and novel targeted therapies in development in CCA. 
Table 2: Clinical trials of targeted therapies in biliary tract cancers (including cholangiocarcinoma)

\begin{tabular}{|c|c|c|c|c|c|c|c|}
\hline Drug & Study & Phase & $\begin{array}{c}\text { Line of } \\
\mathbf{R x} \\
\end{array}$ & $\begin{array}{c}\text { No. of } \\
\text { pts }\end{array}$ & $\operatorname{RR}(\%)$ & $\begin{array}{c}\text { Median PFS } \\
\text { (mths) }\end{array}$ & $\begin{array}{c}\text { Median OS } \\
\text { (mths) }\end{array}$ \\
\hline \multicolumn{8}{|l|}{$\begin{array}{l}\text { Phase III } \\
\text { study }\end{array}$} \\
\hline $\begin{array}{l}\text { GEMOX + } \\
\text { Erlotinib (A) } \\
\text { vs. GEMOX } \\
\text { (B) }\end{array}$ & Lee et al. [35] & III & $1 \mathrm{st}$ & 268 & $\begin{array}{l}\text { A: } 30 \\
\text { B: } 16\end{array}$ & $\begin{array}{l}\text { A: } 5.8 \\
\text { B: } 4.2\end{array}$ & $\begin{array}{l}A: 9.5 \\
B: 9.5\end{array}$ \\
\hline $\begin{array}{l}\text { Phase I/II } \\
\text { studies }\end{array}$ & & & & & & & \\
\hline \multicolumn{8}{|c|}{$E G F R$} \\
\hline Erlotinib & \begin{tabular}{|c|} 
Phillips et al. \\
{$[97]$}
\end{tabular} & II & $\begin{array}{l}1 \mathrm{st} / \\
2 \mathrm{nd}\end{array}$ & 42 & 8 & 2.6 & 7.5 \\
\hline $\begin{array}{l}\text { Sorafenib + } \\
\text { Erlotinib }\end{array}$ & $\begin{array}{c}\text { El-Khoueiry et } \\
\text { al. [42] }\end{array}$ & II & $1 \mathrm{st}$ & 30 & 7 & 2 & 6 \\
\hline $\begin{array}{l}\text { GEMOX + } \\
\text { Cetuximab } \\
\end{array}$ & $\begin{array}{c}\text { Gruenberger et } \\
\text { al. [98] }\end{array}$ & II & $1 \mathrm{st}$ & 30 & 63 & 8.8 & 15.2 \\
\hline $\begin{array}{l}\text { GEMOX + } \\
\text { Cetuximab }\end{array}$ & $\begin{array}{c}\text { Paule et al. } \\
{[99]}\end{array}$ & II & 2nd & 9 & 33 & $\begin{array}{l}\text { Low EGFR: } 4 \\
\text { High EGFR: } 7\end{array}$ & $\begin{array}{c}\text { Low EGFR: } 7 \\
\text { High EGFR: } \\
9\end{array}$ \\
\hline $\begin{array}{l}\text { GEMOX + } \\
\text { Cetuximab (A) } \\
\text { vs. GEMOX } \\
\text { (B) }\end{array}$ & $\underset{[36]}{\text { Malka et al. }}$ & II & $1 \mathrm{st}$ & 150 & $\begin{array}{l}\text { A: } 23 \\
\text { B: } 29\end{array}$ & $\begin{array}{l}\text { A: } 6 \\
\text { B: } 5.3\end{array}$ & $\begin{array}{c}\text { A: } 11 \\
\text { B: } 12.4\end{array}$ \\
\hline $\begin{array}{l}\text { GEMOX + } \\
\text { Cetuximab (A) } \\
\text { vs. GEMOX } \\
\text { (B) }\end{array}$ & $\begin{array}{c}\text { Chen et al. } \\
{[37]}\end{array}$ & II & $1 \mathrm{st}$ & 122 & $\begin{array}{l}\text { A: } 27 \\
\text { B: } 15\end{array}$ & $\begin{array}{l}\text { A: } 6.7 \\
\text { B: } 4.1\end{array}$ & $\begin{array}{l}\text { A: } 10.6 \\
\text { B: } 9.8\end{array}$ \\
\hline $\begin{array}{l}\text { Gemcitabine/ } \\
\text { Capecitabine/ } \\
\text { Cetuximab } \\
\end{array}$ & $\begin{array}{c}\text { Rubovszky et } \\
\text { al. [100] }\end{array}$ & II & Any & 34 & 17.6 & 8.6 & 15.7 \\
\hline $\begin{array}{l}\text { Gemcitabine/ } \\
\text { Cetuximab }\end{array}$ & $\begin{array}{c}\text { Borbath et al. } \\
{[101]}\end{array}$ & II & $1 \mathrm{st}$ & 44 & 20.4 & \begin{tabular}{|c|}
6 month PFS: \\
$47 \%$
\end{tabular} & 13.5 \\
\hline $\begin{array}{l}\text { GEMOX/ } \\
\text { Capecitabine/ } \\
\text { Panitumumab } \\
\end{array}$ & $\begin{array}{c}\text { Jensen et al. } \\
{[102]}\end{array}$ & II & Any & 46 & 33 & 8.3 & 10 \\
\hline $\begin{array}{l}\text { GEMOX + } \\
\text { Panitumumab } \\
\text { (KRAS WT) } \\
\end{array}$ & $\begin{array}{c}\text { Hezel et al. } \\
{[103]}\end{array}$ & II & $1 \mathrm{st}$ & 31 & 45 & 10.6 & 20.3 \\
\hline $\begin{array}{l}\text { Gemcitabine/ } \\
\text { irinotecan/ } \\
\text { Panitumumab }\end{array}$ & \begin{tabular}{|} 
Sohal et al. \\
{$[104]$}
\end{tabular} & II & $1 \mathrm{st}$ & 21 & 43 & NR & 12.7 \\
\hline \multicolumn{8}{|c|}{ HER-2 } \\
\hline Lapatinib & $\begin{array}{c}\text { Ramanathan et } \\
\text { al. [105] }\end{array}$ & II & $\begin{array}{l}1 \mathrm{st} / \\
2 \mathrm{nd}\end{array}$ & 17 & 0 & 1.8 & 5.2 \\
\hline \multicolumn{8}{|c|}{$\begin{array}{l}V E G F / \\
V E G F R\end{array}$} \\
\hline $\begin{array}{l}\text { GEMOX + } \\
\text { Bevacizumab }\end{array}$ & Zhu et al. [39] & II & $\begin{array}{l}1 \mathrm{st} / \\
2 \mathrm{nd}\end{array}$ & 35 & 40 & 7 & 12.7 \\
\hline $\begin{array}{l}\text { Bevacizumab + } \\
\text { Erlotinib }\end{array}$ & $\begin{array}{c}\text { Lubner et al. } \\
{[40]}\end{array}$ & II & $1 \mathrm{st}$ & 49 & 12 & 4.4 & 9.9 \\
\hline $\begin{array}{l}\text { Gemcitabine }+ \\
\text { Capecitabine }+ \\
\text { Bevacizumab }\end{array}$ & Iyer et al. [41] & II & $1 \mathrm{st}$ & 50 & 72 & 8.1 & 11.3 \\
\hline Sorafenib & $\begin{array}{c}\text { El-Khoueiry et } \\
\text { al. }[43]\end{array}$ & II & $1 \mathrm{st}$ & 31 & 0 & 3 & 9 \\
\hline Sorafenib & Bengala [45] & II & Any & 46 & 2 & 2.3 & 4.4 \\
\hline
\end{tabular}




\begin{tabular}{|c|c|c|c|c|c|c|c|}
\hline $\begin{array}{l}\text { Gemcitabine }+ \\
\text { Sorafenib } \\
\text { (A) vs. } \\
\text { Gemcitabine } \\
\text { (B) }\end{array}$ & $\underset{[44]}{\text { Moehler et al. }}$ & II & $1 \mathrm{st}$ & 102 & $\begin{array}{l}\text { A: } 8 \\
\text { B: } 6\end{array}$ & $\begin{array}{c}\text { A: } 3 \\
\text { B: } 4.9\end{array}$ & $\begin{array}{l}\text { A: } 8.4 \\
\text { B: } 11.2\end{array}$ \\
\hline $\begin{array}{l}\text { Gemcitabine/ } \\
\text { Cisplatin + } \\
\text { Sorafenib }\end{array}$ & Lee et al. [46] & II & $1 \mathrm{st}$ & 39 & NR & 6.5 & 14.4 \\
\hline Sunitinib & Yi et al. [47] & II & 2nd & 56 & 9 & 1.7 & 4.8 \\
\hline $\begin{array}{l}\text { Gemcitabine/ } \\
\text { cisplatin + } \\
\text { Cediranib (A) } \\
\text { vs. } \\
\text { Gemcitabine/ } \\
\text { cisplatin (B) } \\
\end{array}$ & $\begin{array}{r}\text { Valle et al. } \\
{[49]}\end{array}$ & II & $1 \mathrm{st}$ & 124 & $\begin{array}{l}\text { A: } 44 \\
\text { B: } 19\end{array}$ & $\begin{array}{c}\text { A: } 8 \\
\text { B: } 7.4\end{array}$ & $\begin{array}{l}\text { A: } 14.1 \\
\text { B: } 11.9\end{array}$ \\
\hline Vandetanib & $\begin{array}{c}\text { Santoro et al. } \\
{[48]}\end{array}$ & II & $1 \mathrm{st}$ & 173 & 4 & 105 days & 228 days \\
\hline \multicolumn{8}{|c|}{$C-M E T$} \\
\hline $\begin{array}{l}\text { Tivantinib + } \\
\text { Gemcitabine } \\
\end{array}$ & Pant et al. [52] & I & Any & 20 & 20 & NR & NR \\
\hline Cabozanitib & $\begin{array}{c}\text { Goyal et al. } \\
{[53]}\end{array}$ & II & $\begin{array}{c}2 \mathrm{nd} \& \\
\text { beyond }\end{array}$ & 19 & 0 & 1.8 & 5.2 \\
\hline \multicolumn{8}{|l|}{ Others } \\
\hline Selumetinib & $\begin{array}{c}\text { Bekaii-Saab et } \\
\text { al. [80] }\end{array}$ & II & $\begin{array}{l}1 \mathrm{st} / \\
2 \mathrm{nd}\end{array}$ & 28 & 12 & 3.7 & 9.8 \\
\hline $\begin{array}{l}\text { Selumetinib + } \\
\text { Gemcitabine/ } \\
\text { cisplatin }\end{array}$ & $\begin{array}{c}\text { Bridgewater et } \\
\text { al.[81] }\end{array}$ & I & $1 \mathrm{st}$ & 12 & \begin{tabular}{|c|}
$37.5 \%$ \\
evaluable \\
pts $)$
\end{tabular} & 6.4 & NR \\
\hline Bortezomib & $\begin{array}{c}\text { Denlinger et } \\
\text { al. [85] }\end{array}$ & II & $\begin{array}{c}2 \mathrm{nd} / \\
3 \mathrm{rd}\end{array}$ & 20 & 5 & 1.6 & 9.5 \\
\hline
\end{tabular}

Abbreviations: PFS, Progression free survival; OS, Overall survival; Rx, Treatment ; NR, Not reported; Pts, Patients

\section{ESTABLISHED MOLECULAR ABERRATIONS AND TARGETED THERAPY}

\section{EGFR/HER2}

The EGFR family comprise of ERBB1-4, with $E R B B 1(E G F R)$ and ERBB2 (HER2) being frequently implicated in the multi-step carcinogenesis of CCA [15]. Binding of EGF-ligands to the receptors induce homodimerization or heterodimerization, which in turn activates downstream signaling pathways (MAPK, PI3K/ $A K T / M T O R$ and $S T A T$ ) that regulates cell differentiation, migration, angiogenesis and survival. EGFR overexpression occurs in $11-27 \%$ of ICC and $5-19 \%$ of ECC, and has been associated with tumor recurrence and worsened survival $[15,17,18]$. Majority $(77-79 \%)$ of EGFR overexpression in BTCs exhibit copy number gain, with activating mutations in $E G F R$ being extremely rare [15]. Although no mutations have been reported in HER2, HER 2 overexpression has been noted in $0-2 \%$ of ICC and $5-20 \%$ of ECC [18]. Preclinical studies have demonstrated that overexpression of HER2 in transgenic mouse models and orthotopic transplantation BDEneu models enhance the development of CCA, and provided consistent evidence of the oncogenic potential of EGFR [34].

Despite the strong rationale of targeting EGFR in BTCs and early interesting results with single arm phase II trials suggesting the benefits of EGFR inhibitors either as single agents or in combination with chemotherapy (Table 2), four completed randomized studies have failed to confirm the benefits of targeting EGFR in advanced BTCs. The only phase III trial of 133 patients with BTCs demonstrated that the addition of erlotinib to gemcitabineoxaliplatin (GEMOX) significantly improved RR, but did not demonstrate any benefit in survival, with a median OS of 9.5 months in both arms [35]. However, subgroup analyses showed that for patients with CCA, the addition of erlotinib to chemotherapy significantly prolonged median PFS by 2.9 months [5.9 months $v s .3 .0$ months (HR 0.73, 95\% CI 0.53-1.00; $P=0.049$ )]. In a phase II study, the addition of cetuximab, a chimeric anti-EGFR monoclonal antibody to GEMOX did not confer a survival benefit in patients with advanced BTCs [36]. The median PFS was 6.1 months for the GEMOX and cetuximab 
Table 3: FGFR2 translocations in ICC

\begin{tabular}{|c|c|c|c|c|}
\hline Study & $\begin{array}{c}\text { No. of } \\
\text { patients (n) }\end{array}$ & $\begin{array}{c}\text { No. of patients with } \\
\text { FGFR2 translocation } \\
\text { (n, \%) }\end{array}$ & $\begin{array}{c}\text { Type of FGFR2 } \\
\text { Translocations }\end{array}$ & Method \\
\hline Wu et al. [59] & 2 & $2(100 \%)$ & $F G F R 2-B I C C 1$ & RNA, exome sequencing \\
\hline Borad et al. [30] & 6 & $3(50 \%)$ & $\begin{array}{c}F G F R 2-T A C C 3 \\
F G F R 2-B I C C 1 \\
F G F R 2-M G E A 5\end{array}$ & $\begin{array}{c}\text { Genome-wide and whole } \\
\text { transcriptome sequencing }\end{array}$ \\
\hline Graham et al. [29] & 96 & $12(13 \%)$ & NR & $\begin{array}{c}\text { Fluorescence in situ } \\
\text { hybridization }\end{array}$ \\
\hline Arai et al. [28] & 66 & $9(13.6 \%)$ & $\begin{array}{c}F G F R 2-A H C Y L 1 \\
F G F R 2-B I C C 1\end{array}$ & Whole transcriptome sequencing \\
\hline Ross et al.[17] & 28 & $3(10.7 \%)$ & $\begin{array}{c}F G F 2-K I A A 1598 \\
F G F R 2-B I C C 1 \\
F G F R 2-T A C C 3\end{array}$ & Next generation sequencing \\
\hline Sia et al. [31] & 107 & $48(45 \%)$ & $\begin{array}{c}F G F R 2-P P H L N 1 \\
F G F R 2-B I C C 1\end{array}$ & RNA, exome sequencing \\
\hline Nakamura et al. [60] & 109 & $6(5.5 \%)$ & $\begin{array}{l}F G F R 2-K C T D 1 \\
F G F R 2-T X L N A \\
F G F R 2-B I C C 1(T y p e ~ 2)\end{array}$ & Exome sequencing \\
\hline
\end{tabular}

Abbreviations: NR, Not reported

arm, compared to 5.5 months in the GEMOX alone arm, and the median OS was 11.0 months and 12.4 months, respectively. In another study, patients who were stratified by KRAS status, received GEMOX with or without cetuximab [37]. The addition of Cetuximab to GEMOX was associated with a trend in improvement in PFS (6.7 months vs. 4.1 months; $P=0.05)$, but not OS (10.6 months vs. 9.8 months; $P=0.91)$. In addition, KRAS mutation did not predict for benefit in survival. The addition of another $E G F R$ antibody, panitumumab to gemcitabine/cisplatin based chemotherapy did not improve survival in patients with advanced BTCs [38]. Additional biomarker-driven trials will provide further insight as most of the studies were conducted in patients who were unselected for KRAS mutation status or other signatures implicated in predicting response to $E G F R$ therapy.

\section{VEGF}

The most potent angiogenic factor in perpetuating tumor growth and metastasis is the vascular endothelial growth factor. $V E G F$ overexpression was observed in $54 \%$ of ICC and $59 \%$ of ECC, and has been shown to promote metastasis, tumor recurrence and confer a worse prognosis $[15,18]$.

The efficacy of $V E G F$ inhibitors has been investigated in several trials (Table 2). Bevacizumab has been combined with GEMOX, erlotinib or gemcitabine and capecitabine, yielding a PFS of 4-8 months and OS of 10-13 months [39-41]. Five trials have investigated sorafenib, a multikinase inhibitor against VEGFR-2, $V E G F R-3, R A F$, platelet derived growth factor receptor $(P D G F R)$ and stem cell factor (KIT), and did not report any significant benefit in survival [42-46]. Other $V E G F$ inhibitors such as sunitinib [47] and vandetanib (ZD6474) [48] yielded disappointing results. Recently, Valle and colleagues reported the results of $\mathrm{ABC}-03$ trial in which the addition of cediranib, a potent oral VEGFR 1-3 inhibitor, was evaluated in combination of gemcitabine/ cisplatin in advanced BTCs in a randomized phase II trial [49]. Of the 124 patients enrolled (62 in each arm), the addition of cediranib improved the response rate $(44 \%$ in the cediranib arm and $19 \%$ in the placebo arm, $P=$ 0.004 ) but did not improve the median PFS (8.0 months in cediranib arm and 7.4 months in placebo arm, HR 0.93, $P=0.72)$ or OS (14.1 months in cediranib arm and 11.9 months in placebo arm, HR $0.86, P=0.44)$. Whether other antiangiogenic agents have any benefits in BTCs and whether any biomarkers have any predictive values in BTCs remain to be investigated.

\section{MET}

Binding of hepatocyte growth factor ( $H G F$ ) to $H G F$ receptor (c-MET) activates multiple key downstream signaling pathways such as the RAS/MAPK, PI3K/ $A K T$ and $J A K / S T A T$, which play critical roles in tumor proliferation and survival [50]. Activation of MET can arise via mutations or copy number amplification. Through gene expression profiling, increased $c-M E T$ expression was observed in $20-60 \%$ of ICC and $0-70 \%$ of ECC [20, 50]. Accumulating evidence has established that $M E T$ overexpression is associated with a poor prognosis. There is emerging evidence that suggest $M E T$ aberration to be one of the mechanisms responsible for EGFR resistance [51]. This led to the evolution of MET inhibitors for CCA, 
Table 4: Targeted therapies in development

\begin{tabular}{|c|c|c|c|c|}
\hline Drug & Target & Phase & Line of therapy & NCT number \\
\hline AG-120 & $I D H 1$ & $\mathrm{I}$ & 2nd \& beyond & NCT02073994 \\
\hline IDH305 & IDH1 & $\mathrm{I}$ & 2nd \& beyond & NCT02381886 \\
\hline AG-221 & $\mathrm{IDH} 2$ & $\mathrm{I} / \mathrm{II}$ & 2nd \& beyond & NCT02273739 \\
\hline Dasatinib & $I D H 1 / 2$ & II & 2nd \& beyond & NCT02428855 \\
\hline BAY1187982 & FGFR2 & $\mathrm{I}$ & 2nd \& beyond & NCT02368951 \\
\hline ARQ087 & FGFR2 & $\mathrm{I} / \mathrm{II}$ & 2nd \& beyond & NCT01752920 \\
\hline BAY1179470 & FGFR2 & $\mathrm{I}$ & Any & NCT01881217 \\
\hline AZD4547 & FGFR2 & $\mathrm{I}$ & Any & NCT00979134 \\
\hline BGJ398 & FGFR2 & II & 2nd \& beyond & NCT02150967 \\
\hline Ponatinib Hydrochloride & FGFR2 & II & Any & NCT02265341 \\
\hline BLU-554 & FGFR4 & $\mathrm{I}$ & Any & NCT02508467 \\
\hline $\begin{array}{l}\text { Erlotinib + } \\
\text { Cetuximab }\end{array}$ & $E G F R$ & I & Any & NCT00397384 \\
\hline $\begin{array}{l}\text { GEMOX } \pm \\
\text { Cetuximab }\end{array}$ & $E G F R$ & II & $1 \mathrm{st}$ & NCT01267344 \\
\hline $\begin{array}{c}\text { GEMOX } \pm \\
\text { Panitumumab }\end{array}$ & $E G F R$ & II & $1 \mathrm{st}$ & NCT01389414 \\
\hline $\begin{array}{c}\text { GEMOX/Capecitabine } \pm \\
\text { Panitumumab } \\
\end{array}$ & $E G F R$ & II & Any & NCT00779454 \\
\hline $\begin{array}{c}\text { GEMOX } \pm \\
\text { Panitumumab }\end{array}$ & $E G F R$ & II & $1 \mathrm{st}$ & NCT01389414 \\
\hline $\begin{array}{l}\text { Gemcitabine/cisplatin + BIBW } \\
2992 \\
\end{array}$ & EGFR/HER2 & I & $1 \mathrm{st}$ & NCT01679405 \\
\hline Afatinib + Capecitabine & EGFR/HER2 & $\mathrm{I}$ & 2nd \& beyond & NCT02451553 \\
\hline ASLAN001 & EGFR, HER2, HER4 & II & 2nd \& beyond & NCT02609958 \\
\hline Cediranib + mFOLFOX6 & $V E G F$ & II & $1 \mathrm{st}$ & NCT01229111 \\
\hline $\begin{array}{l}\text { Gemcitabine + Oxaliplatin + } \\
\text { Capecitabine + Panitumumab/ } \\
\text { Bevacizumab }\end{array}$ & $E G F R, V E G F$ & II & $1 \mathrm{st}$ & NCT01206049 \\
\hline Ramucirumab & $V E G F R$ & II & 2nd \& beyond & NCT02520141 \\
\hline Lenvatinib & $V E G F R$ & II & 2nd \& beyond & NCT02579616 \\
\hline LY2801653 & $c-M E T$ & $\mathrm{I}$ & 2nd \& beyond & NCT01285037 \\
\hline Everolimus & MTOR & $\mathrm{I}$ & 2nd \& beyond & NCT00949949 \\
\hline Trametinib & $M E K$ & II & 2nd \& beyond & NCT02042443 \\
\hline MK2206 & $A K T$ & II & 2nd & NCT01425879 \\
\hline LDK378 & $R O S 1$ & II & 1 st or 2 nd & NCT02374489 \\
\hline Ceritinib & $A L K$ & II & 2nd \& beyond & NCT02638909 \\
\hline Sorafenib + GEMOX & $\begin{array}{l}\text { VEGFR, } \\
P D G F R, \\
R A F, K I T\end{array}$ & $\mathrm{I} / \mathrm{II}$ & $\begin{array}{l}\text { Phase 1: Any } \\
\text { Phase II: } 1 \text { st }\end{array}$ & NCT00955721 \\
\hline Regorafenib & \begin{tabular}{|cccc} 
EGFR, & Ras, & Raf, & VEGFR, \\
& $P D G F R$ & \\
\end{tabular} & II & 2nd & NCT02053376 \\
\hline Regorafenib & \begin{tabular}{|cccc} 
EGFR, & Ras, & Raf, & VEGFR, \\
& $P D G F R$ & \\
\end{tabular} & II & 2nd \& beyond & NCT02115542 \\
\hline Pazopanib + GSK1120212 & $\begin{array}{c}\text { VEGFR/ } \\
P D G F R \\
/ R a f / M E K \\
\end{array}$ & I & Any & NCT01438554 \\
\hline Gemcitabine + Pazopanib & $\begin{array}{ccc}c-K I T, & F G F R, \quad P D G F R & \text { and } \\
V E G F R & \\
\end{array}$ & II & $1 \mathrm{st}$ & NCT01855724 \\
\hline Pembrolizumab & $P D-1$ & II & 2nd \& beyond & NCT02628067 \\
\hline Pembrolizumab + mFOLFOX & $P D-1$ & $\mathrm{I} / \mathrm{II}$ & Any & NCT02268825 \\
\hline MEDI4736 & $P D-L 1$ & $\mathrm{I}$ & 2nd \& beyond & NCT01938612 \\
\hline
\end{tabular}




\begin{tabular}{|c|c|c|c|c|}
\hline $\begin{array}{c}\text { Gemcitabine/Cisplatin } \pm \\
\text { CX-4945 }\end{array}$ & CK2 & I/II & 1st & NCT02128282 \\
\hline BBI503 & Cancer stemness kinase & II & 2nd \& beyond & NCT02232633 \\
\hline DKN-01 $\begin{array}{c}\text { and Gemcitabine/ } \\
\text { Cisplatin }\end{array}$ & Dkk-1 & I & 1 st & NCT02375880 \\
\hline ADH-1 & ICAM-1 & I & 1st & NCT01825603 \\
\hline
\end{tabular}

Abbreviations: $C K 2$, Caesin kinase 2; ICAM-1, Intercellular adhesion molecule-1, Dkk-1, dickkopf $W n t$ signaling pathway inhibitor 1; mFOLFOX; Modified fluorouracil, folinic acid and oxaliplatin.

either alone or in combination with cytotoxic agents.

The combination of Tivantinib (ARQ 197) with gemcitabine was examined in 74 patients with solid tumors, with $20 \%$ ( 1 CCA patient) achieving partial response [52]. In another study, 19 CCA patients who were unselected for $M E T$ amplification or overexpression were treated with cabozantinib and exhibited no objective responses [53]. PFS and OS were 1.77 (95\% CI 1.63-5.37) and $5.2(95 \%$ CI $2.70-8.17)$ months, respectively.

\section{NOVEL ONCOGENIC DRIVERS}

The advent of next generation sequencing techniques has further shaped the genomic landscape of CCA and enhanced our understanding of its pathogenesis. Recent discoveries include $I D H 1 / 2$ mutations, FGFR 2 and ROS1 fusions, and mutations in chromatin remodeling genes for example ARIDIA and BAP1. We will further elaborate on these promising molecular targets.

\section{IDH mutations}

IDH1 and 2 alterations exist in several tumors including gliomas and more recently identified in BTCs through high throughput molecular profiling [15-17, $21,25-27,54] . I D H 1$ and $I D H 2$ are metabolic enzymes that catalyze the oxidative decarboxylation of isocitrate to alpha-ketoglutarate [55]. IDH mutations enhance the conversion of alpha-ketoglutarate to 2-hydroxyglutarate (2-HG), an oncometabolite that inhibits $\alpha$-ketoglutaratedependent enzymes responsible for DNA methylation, epigenetic regulation and call signaling. The accumulation of 2-HG in tumor tissue in turn promotes cell proliferation and survival.

The frequency of $I D H$ mutations ranges from 16$36 \%$, and is ubiquitously higher in ICC than ECC [15-17, $25-27,54,55] . I D H$ mutations were observed in $22-36 \%$ of ICC and only $0-7 \%$ of ECC, and may be associated with clear cell or poorly differentiated histology $[26,55]$. The prognostic significance of $I D H$ mutations remains conflicting. In a cohort of 326 patients with resected ICC, $I D H$ mutation was associated with longer time to recurrence and OS [27]. In addition, the authors observed enhanced $p 53$ and DNA hypermethylation among patients with $I D H$ mutations. In contrast, Jiao et al. demonstrated in a study of 32 patients with ICC that $I D H$ mutations confer a worse prognosis when compared to those with $I D H$ wild-type (3-year OS $33 \%$ vs. $81 \%$; $P=0.003$ ) [24]. However, this adverse finding may be due to the presence of a larger proportion of stage IV disease amongst the $I D H$ mutants compared to $I D H$ wild-type (50\% vs. $15 \%)$. Two recent studies revealed no correlation between $I D H$ mutation status and survival among 200 patients with resected ICC [21] and 104 patients with advanced ICC [54].

Two proof of concept studies illustrated the tumor suppressive effects of $I D H$ inhibitors. Rohle et al. found that a selective R132H-IDH1 inhibitor (AGI-5198) impeded the growth of $I D H$-mutant glioma cells [56]. Similarly, Wang et al. showed that AGI-6780 selectively inhibits the leukemic cells harboring mutant IDH2/ R140Q [57]. Current $I D H$-inhibitor studies are in early clinical development (NCT02073994, NCT02381886 and NCT02273739). The preliminary results of a phase 1 trial of AG120 (IDH1 inhibitor) in 62 patients with IDH1 mutation positive solid tumors who had progressed on standard treatment was reported at the AACR-NCIEORTC International Conference on Molecular Targets and Cancer Therapeutics 2015. There were no dose limiting toxicities, with anemia being the most frequent Grade 3 AE (5\%). 1/20 (5\%) CC patients attained PR and $11 / 20(55 \%)$ attained SD. Reduction in circulating 2 -HG level was observed ranging from $73 \%$ to $99 \%$, and reduction in Ki67 staining was seen from $22 \%-96 \%$. The expansion phase with $500 \mathrm{mg}$ QD is underway (NCT02073994).

\section{Fibroblast growth factor receptor (FGFR) 2 fusions}

$F G F R 2$, a member of the fibroblast growth factor family of receptors (FGFR 1-4), is located at chromosome $10 \mathrm{q} 26$ and mitigates cell differentiation, proliferation and apoptosis [58]. The oncogenic property of FGFR2 has been linked to loss of the carboxy terminus and ligand independent dimerization, leading to $F G F R$ protein overexpression.

Whole exome sequencing and fluorescence in situ hybridization (FISH) have identified FGFR2 alterations primarily in $6 \%-50 \%$ of ICC and $0-5 \%$ of ECC [28-31, $59,60]$. Churi et al. analyzed 75 CCA patients with next generation sequencing, and found that genetic alterations 
in the FGFR pathway occurred in $13 \%$ of intrahepatic CCA and $5 \%$ of extrahepatic CCA, and that these alterations were associated with improved survival [16].

More recently, FGFR2 fusions have been detected in several studies (Table 3 ). These fusions are a product of the FGFR receptor (exons 1-19) and various partners (e.g. AHCYL1, BICC1, KCTD1 and TXLNA). The fusion protein is activated by the enforced dimerization of the respective partners with resultant intracellular domain tyrosine residue phosphorylation, and activation of downstream signaling pathways including $M A P K, P I K 3 /$ $A K T / M T O R$ and $J A K / S T A T$ pathways [59]. There are marked variability in the frequency of FGFR2 fusions, ranging from $6-50 \%$ in ICC, and rarely in ECC. In a series of 102 patients with BTCs, Arai et al. observed FGFR2 fusions (FGFR2-AHCYL1 or FGFR2-BICC1) in 13.6\% of ICC (9/66 ICC), and that inhibition of FGFR2 impeded activation of $M A P K$ pathway, which is responsible for uncontrolled tumor growth [28]. Another study evaluated 152 CCA and 4 intraductal papillary biliary neoplasm of the bile duct with FISH, and reported FGFR2 translocation in $12 / 96(13 \%)$ of ICC, with a female predominance [29]. Those who harbored FGFR2 translocations had improved cancer-specific survival (123 vs. 37 months) and superior DFS (125 months vs. 26 months). Furthermore, cholangiocarcinoma harboring FGFR2 translocation and concomitant KRAS mutation are only rarely reported [31]. Therefore, this association remains to be explored in larger cohorts to further assess if FGFR2 translocation work in synergy with KRAS mutation in promoting carcinogenesis in CCA. In a study comprising of 109 ICC, 40 ECC and 11 gallbladder cases, novel FGFR2 gene fusions (FGFR2KCTD1 and FGFR2-TXLNA) and a new variation of FGFR2-BICC (Type 2) were reported [60]. Using NIH3T3 clones that express either wild-type or kinase-inactive mutant forms of FGFR2-KCTD1 or FGFR2-TXLNA, the Nakamura et al. showed that wild-type $F G F R$ fusions, and not the mutant forms induce tumor growth in vivo via ligand-independent autophosphorylation and activation of the $M A P K$ signaling pathway. In addition, there was marked inhibition of FGFR autophosphorylation and cell proliferation by the FGFR inhibitors (BGJ398 and

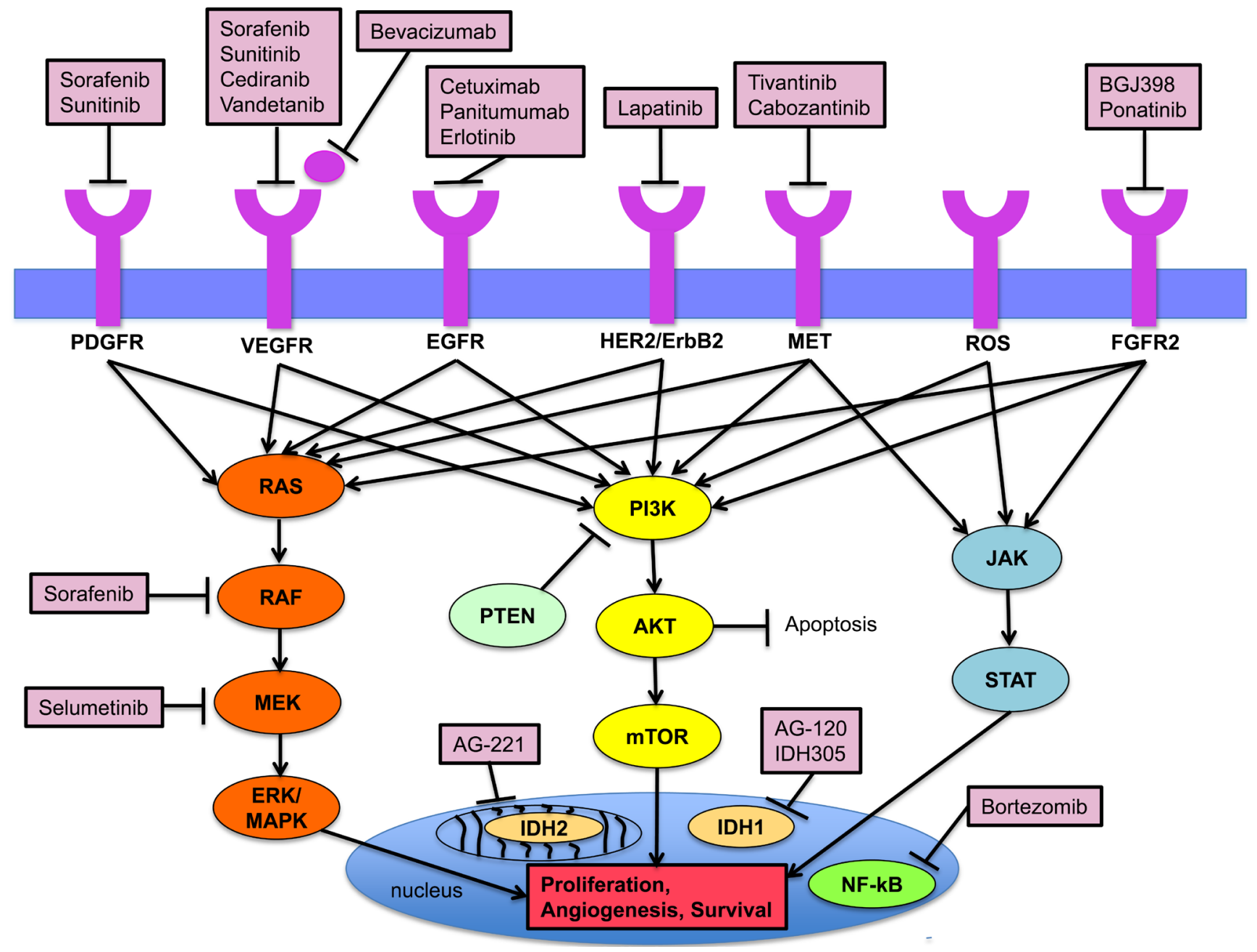

Figure 1: Key signaling pathways in the pathogenesis of cholangiocarcinoma and established targeted agents. 
PD173474).

In a genome-wide and whole transcriptome sequencing on 6 ICC samples with FGFR 2 translocations in $3 / 6(50 \%)$ patients, two out of three patients responded to FGFR2 inhibitors [30]. One patient with FGFR2$M G E A 5$ fusion was treated with ponatinib (a pan- $F G F R$ inhibitor) and had a biochemical CA 19-9 response with shrinkage of tumor. Another patient with FGFR2-TACC3 fusion who previously achieved a partial response with pazopanib, and subsequently received ponatinib attained stable disease. These encouraging results suggest that FGFR2 has the potential to be an actionable molecular target, and that patients who harbor these alterations may benefit from tyrosine-kinase directed therapies. An ongoing phase 2 study of BGJ398 (a selective pan$F G F R$ inhibitor) in patients with advanced or metastatic CCA with $F G F R$ genetic alterations reported promising efficacy (Javle MM et al, 2016 Gastrointestinal Cancer Symposium, J Clin Oncol 34, 2016 (suppl 4S; abstr $335)$ ) The overall RR was $22 \%$ (8/36 evaluable patients) and DCR was $75 \%$ (27/26 patients). BGJ398 was generally well tolerated. The Grade 3/4 AEs include hyperphosphatemia (19\%), hypophosphatemia (9\%), hyponatremia $(6 \%)$, and asymptomatic increased lipase $(6 \%)$. This is a promising drug that warrants further investigation.

\section{IMMUNE CHECKPOINT INHIBITORS}

Immune checkpoints including cytotoxic T-lymphocyte-associated antigen (CTLA)-4, programmed cell death $(P D)-1$ receptor and its ligands $(P D-L 1, P D$ $L 2)$ promotes T-cell anergy [61]. Increased levels of tumor-infiltrating CD8+ cytotoxic T cells and/or CD4+ $\mathrm{T}$ cells have been shown to be associated with improved prognosis in BTCs [62]. Given the success of ipilimumab (CTLA-4 monoclonal antibody), pembrolizumab and nivolumab (anti- $P D-1$ antibodies) in the treatment of metastatic melanoma $[63,64]$, there has been growing interest of the benefit of immunomodulation in BTCs. In a preclinical study of intrahepatic CCA, Koido et al. showed that both gemcitabine and interferon $-\gamma$ led to an upregulation of $P D-L 1$, which suggest that treatment with $P D-L 1$ blockade may be beneficial [65]. Studies have suggested that mismatch repair (MMR) deficient tumors are more responsive to PD-1 blockade than are MMR proficient tumors [66]. A phase II study demonstrated that pembrolizumab led to high RR in colorectal cancer patients with genetic defects in mismatch repair (MMR) [66]. The phase II study with pembrolizumab in MMR deficient non-colorectal gastrointestinal cancers (ampullary $(n=4)$, pancreas $(n=4)$, biliary $(n=3)$, small bowel $(n=3)$, and gastric ( $n=3)$ cancers) is ongoing. An interim analysis reported an ORR of $50 \%$ and DCR of $70 \%$ in 10 evaluable patients. The OS was 21 months and PFS was not reached (Le DT et al, 2016 Gastrointestinal Symposium, J Clin
Oncol 34, 2016 (suppl 4S; abstr 195)). There are currently no studies evaluating the efficacy of $P D-1$ inhibitors in CCA patients with microsatellite instability (MSI)-high versus MSI-stable tumors. The interim results of another phase $1 \mathrm{~b}$ study of pembrolizumab (MK-3495) in patients with advanced BTC was presented at the European Cancer Congress 2015 (NCT02054806). Pembrolizumab was well tolerated with an ORR of $17.4 \%$ (95\% CI, 5.0-38.8) in the 23 evaluable patients. $4 / 24(16.7 \%)$ of the patients experienced a treatment-related grade $3 \mathrm{AE}$ (anemia, autoimmune hemolytic anemia, colitis, and dermatitis). Currently, pembrolizumab is evaluated in combination with mFOLFOX6 in a phase $1 / 2$ study at the University of Utah (NCT02268825).

\section{LESS-ESTABLISHED MOLECULAR ABERRATIONS}

There has been limited studies regarding the following molecular aberrations and additional studies are required to provide further insight.

\section{ROS1}

Elevated ROS expression has been observed in nonsmall cell lung cancer, glioblastoma and breast cancer [32]. ROS kinase fusions [between kinase domain of ROS and Fused in Glioblastoma $(F I G)$ gene] has been described in $8.7 \%$ of patients with CCA [32]. These fusions further activate downstream effectors such as STAT3 and AKT. The FIG-ROS fusion driver gene has been shown to accelerate tumor growth in an orthotopic allograft mouse model, and that inactivation of the gene portends an antitumor effect [67].

Notably, TAE684 (an $A L K$ inhibitor) has been shown to inhibit ROS kinase activity, with consequent cell inhibition and cell death in $\mathrm{BaF} 3$ cells expressing this fusion protein [32]. Given the success of crizotinib in attaining an impressive response rate of $48 \%$ in ROS1rearranged non-small cell lung cancer [68], similar studies in CCA are warranted to evaluate the potential benefit of targeted therapy in patients with $R O S$ fusions. A phase II trial of crizotinib in patients with $A L K, M E T$ or ROS1 alterations is underway (NCT02034981).

\section{PI3K/AKT/MTOR}

Constitutive activation of the EGFR, HER2, MET and Insulin growth factor $(I G F)$ receptor or disruption of the PTEN and SMAD4 triggers the downstream activation of $P I 3 K / P T E N / A K T / m T O R$ signaling pathway $[69,70]$. Dysregulation of this pathway subsequently stimulates cell proliferation, angiogenesis and survival. Activation of this pathway in patients harboring EGFR, HER2 and $M E T$ overexpression has been reported in as high as $65 \%$ 
of tumors. The incidence of PIK3CA (a subunit of PI3K) hotspot mutations in CCA ranges from $5 \%$ to $34 \%$ [71]. Furthermore, increased expression of phosphor- $A K T 1$ and phosphor-MTOR in intrahepatic CCA is positively correlated with prognosis and that this association was not modified by PTEN expression [72].

Dual inhibition of $A K T$ and MTOR with MK-2206 and everolimus (RAD001) has been shown to enhance anti-proliferative effects in CCA [73]. More recently, increased efficacy was attained in-vitro by dual inhibition of the $P I 3 K / A K T / M T O R$ and $R A F / M E K / E R K$ pathway, which overcame resistance pathways [74]. A phase I trial of mFOLFOX6 and the oral PI3K inhibitor BKM120 in patients with advanced solid tumors (4/17 CCA) reported high toxicity rates, with $76 \%$ of the patients experiencing a grade $3 / 4 \mathrm{AE}$ [75]. The most common AEs were neutropenia, fatigue, leukopenia, hyperglycemia and thrombocytopenia. 1/4 of the CCA patients achieved SD. The combination of everolimus with gemcitabine and cisplatin was evaluated in $10 \mathrm{CCA}$ and gallbladder cancers, of which 60\% had SD [76]. Currently, MK2206 ( $A K T$ inhibitor) is being investigated in advanced refractory BTC (NCT01425879).

\section{RAS/RAF/MEK/ERK}

The $R A S / R A F / M E K / E R K$ signal transduction pathway is frequently dysregulated in BTCs [77]. Activation of this pathway requires the binding of $E G F$, $P D G F$ and cytokines to its receptors, with subsequent transactivation of downstream signaling cascade, leading to the end-phosphorylation of MEK1 and 2 and $E R K-1$ and $E R K-2$. $M E K$ is an attractive target as $E R K-1$ and $E R K-2$ are the only known $M E K$ substrates [70]. Gain of function mutations in KRAS constitutes one of the most frequent mutations in CCA, with the most frequent alteration in codon 12 [15]. The frequency of activating $K R A S$ mutations ranges from 9\%-40\% [15-17]. KRAS has been associated with perineural invasion and poor prognosis [78]. In addition, there is marked anatomical variability in $K R A S$ mutation, with KRAS mutations observed in $53.3 \%$ of perihilar-type, but only $16.7 \%$ of intrahepatic CCA. Notably, the incidence of KRAS mutations increases with disease stage.[79] Despite the recognized frequency of $K R A S$ mutations, targeting this pathway remains challenging. Early evidence of efficacy of $M E K$ inhibitor was reported in a single arm study of selumetinib in advanced BTCs [80]. Of the 28 patients enrolled, 3 patients had confirmed partial responses. In this study, no $B R A F$ V600E mutations were found. Recently, the ABC-04 study of selumetinib in combination with gemcitabine and cisplatin in advanced or metastatic BTC (9/13 CCA) demonstrated a RR of 37.5\%, a median PFS of 6.4 months and manageable toxicities [81].

\section{BRAF}

$B$-Raf is a proto-oncogene and is a key component of the $R A S / R A F / M E K / E R K$ proliferation signaling pathway. The most common $B R A F$ gene mutation found in human cancers is V600E, and exists in up to $22 \%$ of CCA in one report [82]. More importantly, $B R A F$ and $K R A S$ mutations are mutually exclusive. In a recent phase II "basket" study of vemurafenib in BRAF V600 mutated non-melanoma cancers, one patient with CCA achieved a durable PR of more than one year [83].

\section{NFk-B}

Several studies have suggested the $N F-k B$, a transcriptional nuclear factor, plays a critical role in tumor migration and treatment resistance in several tumors, although the evidence is not conclusive [84]. This stems from the observation that tumor proliferation can be kept in check via proteasome inhibition, which halts the clearance of pro-apoptotic factors. To date, the only proteasome inhibitor investigated was bortezomib and results were disappointing, with no objective response, median time to progression was 5.8 months and median OS was 9 months [85].

\section{JAK/STAT cytokine pathway}

Binding of pro-inflammatory cytokine, interleukin-6 (IL-6) to gp130 triggers the downstream activation of the $J A K / S T A T$ pathway, leading to the silencing of its inhibitor, suppressor of cytokine signaling-3 (SOCS3) [86]. This in turn accelerates inflammation, cell growth and tumor formation. This pathway has been noted in $70 \%$ of the inflammation subclass in ICC, characterized by activation of the STAT3 and cytokine pathways and improved prognosis.[87] Furthermore, the $J A K 2$ inhibitor AZD1480 has been demonstrated to inhibit Stat3 signaling and exhibit anti-tumor efficacy in solid tumor cell lines [88].

\section{Notch signaling pathways}

The Notch signaling cascade is a highly conserved pathway, responsible for cell differentiation, apoptosis and cell survival. To date, there are four known Notch receptors and five ligands. Aberrant Notch signaling was first described in acute T-cell lymphoblastic leukemia, and subsequently in CCA $[89,90]$. Notch-mediated conversion of hepatocytes into biliary lineage has been shown to promote intrahepatic CCA formation and progression in a mouse model of ICC [91]. Notch 1 and 4 were noted to be more frequently expressed in tumor cells compared to normal tissue. The frequency of Notch expression in 
ICC for Notch 1, Notch 2, Notch 3 and Notch 4 were $82.9 \%, 56.1 \%, 39.0 \%$ and $34.1 \%$ respectively [92]. In addition, Notch 4 was found to be prognostic and Notch 1 overexpressed in large tumors. Furthermore, Notch overexpression has been demonstrated to predict sensitivity to 5-fluorouracil in vivo. The complex Notch signaling pathway warrants further understanding before the advent of novel Notch targeting agents.

\section{Protein kinase $A$ regulatory subunit 1 alpha (PRKAR1A) pathway}

Protein kinase A is a cyclic AMP ( $c A M P)$-dependent protein kinase and is part of the serine-threnonine protein kinase family. Activation of the PRKAR1A/PKAI pathway is found in various tumors, including CCA [93]. More recently, fusion genes comprising of $c A M P$-dependent protein kinase $(P K A)$ and mitochondrial ATP synthase (ATP1B-PRKACA and ATP1B-PRKACB) were detected with resultant increased expression of $P R K A C A$ and $P R K A C B$ and activation of $M A P K$ signaling [60]. The abrogation of $P R K A R 1 A$ gene expression has been linked to significant cell inhibition and apoptosis of CC cells via suppression of the JAK/STAT, MAPK, PI3K/AKT and $W N T / \beta$-catenin pathway signaling. Drug evaluation with $P K A$ inhibitor (isoquinoline $\mathrm{H} 89$ ) as well as sitespecific $c A M P$ analogs (8-Cl $c A M P$ and $8-\mathrm{Br} c A M P$ ) showed promising anti-proliferative effect in CCA cells, supporting the notion that $P K A$ can potentially contribute as a drug target in CCA.

\section{Wnt/ß-catenin pathway}

Aberrant genetic alterations of the Winglesstype MMTV integration site family $(W n t) / \beta$-catenin signaling cascade has been implicated in tumorigenesis in several studies [94]. The Wnt signaling pathway is highly activated in CCA, and an inflammatory milieu comprising of inflammatory macrophages is required for its sustainability [95]. Furthermore, tumor regression in mouse and rat models were prompted with the introduction of $W n t$ inhibitors. The Wnt signaling pathway has also been postulated as one of the mechanisms responsible for chemoresistance in CCA [94]. GSK3 $\beta$, a "destruction complex" phosphorylates and degrade $\beta$-catenin, leading to downregulation of the $W n t$ survival pathway. Recently, Huang et al. showed that $\beta$-escin, an active compound in horse chestnut (Aesculus hippocastanum) seed, could inhibit the GSK3 $\beta / \beta$-catenin pathway and thus terminate cell growth [96]. Hence, the Wnt signaling pathway may represent another alternative target for ICC treatment.

Clinical studies with novel agents in early development are summarized in Table 4.

\section{CONCLUSIONS}

Advanced CCA portends a dismal prognosis despite standard treatment with gemcitabine and cisplatin. Given the modest benefits with chemotherapy alone and the anatomical, pathological and molecular heterogeneity, there is an unmet and imperative need for comprehensive genomic profiling to improve the understanding of the pathogenesis of CCA, with the aim of personalized treatment. To achieve this aim, we must overcome the mounting challenges, which include a lack of RCTs due to the rarity of CCA, and the inherent complexity due to interactions of the signaling pathways. Extensive collaborative efforts will be required to formulate adequately powered biomarker-driven trials to improve clinical outcomes. Results of the EGFR inhibitors have been disappointing. As the majority of the trials are performed in unselected population, it will be informative to conduct trials in patients enriched for the presence of molecular signatures implicated in predicting EGFR sensitivity to determine its efficacy. Given the promising early evidence of efficacy signal with $I D H$ and FGFR2 inhibitors in early phase trials, additional studies should focus on novel strategies targeting $I D H$ mutations and FGFR2 fusions. Furthermore, the identification of oncogenic addiction loops, or novel combination strategy that targets critical molecular pathways simultaneously will be paramount to improve the clinical outcome in CCA.

\section{Abbreviations}

CCA, Cholangiocarcinoma; EGFR, Epidermal growth factor receptor; KRAS, Kirsten rat sarcoma viral oncogene homolog; BRAF, V-raf murine sarcoma viral oncogene homolog; IDH, Isocitrate dehydrogenase, BAP1, BRCA1-Associated Protein 1; ARID1A, ATrich interactive domain-containing protein 1A; FGFR, Fibroblast growth factor receptor; ROS1, ROS protooncogene 1; OS, Overall survival; BTC, Biliary tract cancer; OR, Odds ratio; CI, Confidence interval; RCT, Randomized controlled trials; GC, Gemcitabine and cisplatin; PFS, Progression free survival; HR, Hazard ratio; DCR, Disease control rate; VEGF, Vascular endothelial growth factor; VEGFR, Vascular endothelial growth factor receptor; HER2, Human epidermal growth factor receptor 2; ERBB2, erb-b2 receptor tyrosine kinase 2; MET, MET proto-oncogene; TP 53, Tumor protein $\mathrm{p} 53$; MEK, Mitogen-activated extracellular signal regulated kinase; ERK, Extracellular signal-regulated kinases; PI3K, Phosphatidylinositol 3-kinase; PTEN, Phosphatase and tensin; AKT, Protein kinase B; MTOR, Mechanistic target of rapamycin; NGS, Next generation sequencing; PBRM1, Protein polybromo-1; GEMOX, Gemcitabine-oxaliplatin; PDGFR, Platelet derived growth factor receptor; KIT, 
Stem cell factor, HGF, Hepatocyte growth factor; IGF, Insulin growth factor; SMAD4, Mothers against Decapentaplegic Homolog ; IL-6, Interleukin-6; SOCS3, Suppressor of cytokine signaling-3; ROBO2, Roundabout guidance receptor 2; CDKN2A, Cyclin-dependent kinase inhibitor 2A; PEG3, Paternally expressed 3; RNF, Ring fingers proteins; 2-HG, 2-hydroxyglutarate; FISH, Fluorescence in situ hybridization; PRKAR1A, Protein kinase A regulatory subunit 1 alpha; Wnt, Winglesstype MMTV integration site family; CTLA, Cytotoxic T-lymphocyte-associated antigen, PD, Programmed cell death; PD-L, Programmed cell death ligand; MCL1, Induced myeloid leukemia cell differentiation protein Mcl-1; FBXW7, F-box/WD repeat-containing protein 7; CDK6, Cell division protein kinase 6; NF1, Neurofibromin 1; TSC1, Tuberous sclerosis 1; BRCA, Breast Cancer susceptibility gene; RR, Response rate; CK2, Caesin kinase 2; ICAM-1, Intercellular adhesion molecule-1.

\section{ACKNOWLEDGMENTS}

Both the authors contributed equally to this manuscript.

\section{CONFLICTS OF INTEREST}

The authors declared that they do not have anything to disclose with respect to this manuscript.

\section{FINANCIAL SUPPORT}

Andrew X. Zhu received research funding support from the V Foundation for Cancer Research and Target Cancer Foundation.

Dawn Q. Chong received research funding support from the National Medical Research Council.

\section{REFERENCES}

1. Khan SA, Toledano MB and Taylor-Robinson SD. Epidemiology, risk factors, and pathogenesis of cholangiocarcinoma. HPB (Oxford). 2008; 10:77-82.

2. Siegel R, Naishadham D and Jemal A. Cancer statistics, 2013. CA Cancer J Clin. 2013; 63:11-30.

3. Yang JD, Kim B, Sanderson SO, Sauver JS, Yawn BP, Larson JJ, Therneau TM, Roberts LR, Gores GJ and Kim WR. Biliary tract cancers in Olmsted County, Minnesota, 1976-2008. Am J Gastroenterol. 2012; 107:1256-1262.

4. Zhou Y, Zhao Y, Li B, Huang J, Wu L, Xu D, Yang J and He J. Hepatitis viruses infection and risk of intrahepatic cholangiocarcinoma: evidence from a meta-analysis. BMC Cancer. 2012; 12:289.

5. Nathan H, Pawlik TM, Wolfgang CL, Choti MA, Cameron JL and Schulick RD. Trends in survival after surgery for cholangiocarcinoma: a 30-year population-based SEER database analysis. J Gastrointest Surg. 2007; 11:1488-1496; discussion 1496-1487.

6. Mavros MN, Economopoulos KP, Alexiou VG and Pawlik TM. Treatment and Prognosis for Patients With Intrahepatic Cholangiocarcinoma: Systematic Review and Metaanalysis. JAMA Surg. 2014;149:565-74.

7. Horgan AM, Amir E, Walter T and Knox JJ. Adjuvant therapy in the treatment of biliary tract cancer: a systematic review and meta-analysis. J Clin Oncol. 2012; 30:19341940.

8. Gu J, Bai J, Shi X, Zhou J, Qiu Y, Wu Y, Jiang C, Sun X, Xu F, Zhang Y and Ding Y. Efficacy and safety of liver transplantation in patients with cholangiocarcinoma: a systematic review and meta-analysis. Int J Cancer. 2012; 130:2155-2163.

9. Amini N, Ejaz A, Spolverato G, Kim Y, Herman JM and Pawlik TM. Temporal trends in liver-directed therapy of patients with intrahepatic cholangiocarcinoma in the United States: a population-based analysis. J Surg Oncol. 2014; 110:163-170.

10. Valle J, Wasan H, Palmer DH, Cunningham D, Anthoney A, Maraveyas A, Madhusudan S, Iveson T, Hughes S, Pereira SP, Roughton M, Bridgewater J and Investigators ABCT. Cisplatin plus gemcitabine versus gemcitabine for biliary tract cancer. N Engl J Med. 2010; 362:1273-1281.

11. Ramirez-Merino N, Aix SP and Cortes-Funes $H$. Chemotherapy for cholangiocarcinoma: An update. World J Gastrointest Oncol. 2013; 5:171-176.

12. Lamarca A, Hubner RA, David Ryder W and Valle JW. Second-line chemotherapy in advanced biliary cancer: a systematic review. Ann Oncol. 2014; 25:2328-2338.

13. Sang-Cheol Lee KK, Hanjo Kim, Hyun Jung Kim, Se Hyung Kim, Sang-Byung Bae, Chan Kyu Kim, Namsu Lee, Kyu Taek Lee, Sung Kyu Park, Jong-Ho Won, Jina Yun, Dae Sik Hong, Hee Sook Park. Prognostic factor analysis of second-line chemotherapy in advanced biliary tract cancer. J Clin Oncol 30, 2012 (suppl; abstr e14688).

14. Bridgewater J, Palmer D, Cunningham D, Iveson $\mathrm{T}$, Gillmore R, Waters J, Harrison M, Wasan H, Corrie P and Valle J. Outcome of second-line chemotherapy for biliary tract cancer. Eur J Cancer. 2013; 49:1511.

15. Andersen JB. Molecular pathogenesis of intrahepatic cholangiocarcinoma. J Hepatobiliary Pancreat Sci. 2015; 22:101-113.

16. Churi CR, Shroff R, Wang Y, Rashid A, Kang HC, Weatherly J, Zuo M, Zinner R, Hong D, Meric-Bernstam F, Janku F, Crane CH, Mishra L, Vauthey JN, Wolff RA, Mills G, et al. Mutation profiling in cholangiocarcinoma: prognostic and therapeutic implications. PLoS One. 2014; 9:e115383.

17. Ross JS, Wang K, Gay L, Al-Rohil R, Rand JV, Jones DM, Lee HJ, Sheehan CE, Otto GA, Palmer G, Yelensky R, Lipson D, Morosini D, Hawryluk M, Catenacci DV, Miller VA, et al. New routes to targeted therapy of intrahepatic 
cholangiocarcinomas revealed by next-generation sequencing. Oncologist. 2014; 19:235-242.

18. Yoshikawa D, Ojima H, Iwasaki M, Hiraoka N, Kosuge T, Kasai S, Hirohashi S and Shibata T. Clinicopathological and prognostic significance of EGFR, VEGF, and HER2 expression in cholangiocarcinoma. Br J Cancer. 2008; 98:418-425.

19. Nakazawa K, Dobashi Y, Suzuki S, Fujii H, Takeda Y and Ooi A. Amplification and overexpression of c-erbB-2, epidermal growth factor receptor, and c-met in biliary tract cancers. J Pathol. 2005; 206:356-365.

20. Miyamoto M, Ojima H, Iwasaki M, Shimizu H, Kokubu A, Hiraoka N, Kosuge T, Yoshikawa D, Kono T, Furukawa H and Shibata T. Prognostic significance of overexpression of c-Met oncoprotein in cholangiocarcinoma. Br J Cancer. 2011; 105:131-138.

21. Zhu AX, Borger DR, Kim Y, Cosgrove D, Ejaz A, Alexandrescu S, Groeschl RT, Deshpande V, Lindberg JM, Ferrone C, Sempoux C, Yau T, Poon R, Popescu I, Bauer TW, Gamblin TC, et al. Genomic profiling of intrahepatic cholangiocarcinoma: refining prognosis and identifying therapeutic targets. Ann Surg Oncol. 2014; 21:3827-3834.

22. Ong CK, Subimerb C, Pairojkul C, Wongkham S, Cutcutache I, Yu W, McPherson JR, Allen GE, Ng CC, Wong BH, Myint SS, Rajasegaran V, Heng HL, Gan A, Zang ZJ, Wu Y, et al. Exome sequencing of liver flukeassociated cholangiocarcinoma. Nat Genet. 2012; 44:690693.

23. Chan-On W, Nairismagi ML, Ong CK, Lim WK, Dima S, Pairojkul C, Lim KH, McPherson JR, Cutcutache I, Heng HL, Ooi L, Chung A, Chow P, Cheow PC, Lee SY, Choo $\mathrm{SP}$, et al. Exome sequencing identifies distinct mutational patterns in liver fluke-related and non-infection-related bile duct cancers. Nat Genet. 2013; 45:1474-1478.

24. Jiao Y, Pawlik TM, Anders RA, Selaru FM, Streppel MM, Lucas DJ, Niknafs N, Guthrie VB, Maitra A, Argani P, Offerhaus GJ, Roa JC, Roberts LR, Gores GJ, Popescu I, Alexandrescu ST, et al. Exome sequencing identifies frequent inactivating mutations in BAP1, ARID1A and PBRM1 in intrahepatic cholangiocarcinomas. Nat Genet. 2013; 45:1470-1473.

25. Borger DR, Tanabe KK, Fan KC, Lopez HU, Fantin VR, Straley KS, Schenkein DP, Hezel AF, Ancukiewicz M, Liebman HM, Kwak EL, Clark JW, Ryan DP, Deshpande V, Dias-Santagata D, Ellisen LW, et al. Frequent mutation of isocitrate dehydrogenase (IDH) 1 and IDH2 in cholangiocarcinoma identified through broad-based tumor genotyping. Oncologist. 2012; 17:72-79.

26. Kipp BR, Voss JS, Kerr SE, Barr Fritcher EG, Graham RP, Zhang L, Highsmith WE, Zhang J, Roberts LR, Gores GJ and Halling KC. Isocitrate dehydrogenase 1 and 2 mutations in cholangiocarcinoma. Hum Pathol. 2012; 43:1552-1558.

27. Wang P, Dong Q, Zhang C, Kuan PF, Liu Y, Jeck WR, Andersen JB, Jiang W, Savich GL, Tan TX, Auman JT, Hoskins JM, Misher AD, Moser CD, Yourstone SM, Kim
$\mathrm{JW}$, et al. Mutations in isocitrate dehydrogenase 1 and 2 occur frequently in intrahepatic cholangiocarcinomas and share hypermethylation targets with glioblastomas. Oncogene. 2013; 32:3091-3100.

28. Arai Y, Totoki Y, Hosoda F, Shirota T, Hama N, Nakamura H, Ojima H, Furuta K, Shimada K, Okusaka T, Kosuge T and Shibata T. Fibroblast growth factor receptor 2 tyrosine kinase fusions define a unique molecular subtype of cholangiocarcinoma. Hepatology. 2014; 59:1427-1434.

29. Graham RP, Barr Fritcher EG, Pestova E, Schulz J, Sitailo LA, Vasmatzis G, Murphy SJ, McWilliams RR, Hart SN, Halling KC, Roberts LR, Gores GJ, Couch FJ, Zhang L, Borad MJ and Kipp BR. Fibroblast growth factor receptor 2 translocations in intrahepatic cholangiocarcinoma. Hum Pathol. 2014; 45:1630-1638.

30. Borad MJ, Champion MD, Egan JB, Liang WS, Fonseca $\mathrm{R}$, Bryce AH, McCullough AE, Barrett MT, Hunt K, Patel MD, Young SW, Collins JM, Silva AC, Condjella RM, Block M, McWilliams RR, et al. Integrated genomic characterization reveals novel, therapeutically relevant drug targets in FGFR and EGFR pathways in sporadic intrahepatic cholangiocarcinoma. PLoS Genet. 2014; 10:e1004135.

31. Sia D, Losic B, Moeini A, Cabellos L, Hao K, Revill K, Bonal D, Miltiadous O, Zhang Z, Hoshida Y, Cornella H, Castillo-Martin M, Pinyol R, Kasai Y, Roayaie S, Thung SN, et al. Massive parallel sequencing uncovers actionable FGFR2-PPHLN1 fusion and ARAF mutations in intrahepatic cholangiocarcinoma. Nat Commun. 2015; 6:6087.

32. Gu TL, Deng X, Huang F, Tucker M, Crosby K, Rimkunas V, Wang Y, Deng G, Zhu L, Tan Z, Hu Y, Wu C, Nardone J, MacNeill J, Ren J, Reeves C, et al. Survey of tyrosine kinase signaling reveals ROS kinase fusions in human cholangiocarcinoma. PLoS One. 2011; 6:e15640.

33. Wiggers JK, Ruys AT, Groot Koerkamp B, Beuers $\mathrm{U}$, ten Kate FJ and van Gulik TM. Differences in immunohistochemical biomarkers between intra- and extrahepatic cholangiocarcinoma: a systematic review and meta-analysis. J Gastroenterol Hepatol. 2014; 29:15821594.

34. Kiguchi K, Carbajal S, Chan K, Beltran L, Ruffino L, Shen J, Matsumoto T, Yoshimi N and DiGiovanni J. Constitutive expression of ErbB-2 in gallbladder epithelium results in development of adenocarcinoma. Cancer Res. 2001; 61:6971-6976.

35. Lee J, Park SH, Chang HM, Kim JS, Choi HJ, Lee MA, Jang JS, Jeung HC, Kang JH, Lee HW, Shin DB, Kang HJ, Sun JM, Park JO, Park YS, Kang WK, et al. Gemcitabine and oxaliplatin with or without erlotinib in advanced biliary-tract cancer: a multicentre, open-label, randomised, phase 3 study. Lancet Oncol. 2012; 13:181-188.

36. Malka D, Cervera P, Foulon S, Trarbach $\mathrm{T}$, de la Fouchardiere C, Boucher E, Fartoux L, Faivre S, Blanc JF, Viret F, Assenat E, Seufferlein T, Herrmann T, Grenier J, 
Hammel P, Dollinger M, et al. Gemcitabine and oxaliplatin with or without cetuximab in advanced biliary-tract cancer (BINGO): a randomised, open-label, non-comparative phase 2 trial. Lancet Oncol. 2014; 15:819-828.

37. Chen JS, Hsu C, Chiang NJ, Tsai CS, Tsou HH, Huang SF, Bai LY, Chang IC, Shiah HS, Ho CL, Yen CJ, Lee KD, Chiu CF, Rau KM, Yu MS, Yang Y, et al. A KRAS mutation status-stratified randomized phase II trial of gemcitabine and oxaliplatin alone or in combination with cetuximab in advanced biliary tract cancer. Ann Oncol. 2015; 26:943-949.

38. Arndt Vogel SK, Weichert W, Bitzer M, Block A, Riess $\mathrm{H}$, Schulze-Bergkamen H, Moehler MH, Merx KE, Endris V, Schnoy E, Siveke JT, Miehl P, Walkdschmidt $\mathrm{D}$, et al. Panitumumab in combination with gemcitabine/ cisplatin (GemCis) for patients with advanced kRAS WT biliary tract cancer: A randomized phase II trial of the Arbeitsgemeinschaft Internistische Onkologie (AIO). J Clin Oncol. 2015; 33, (suppl; abstr 4082).

39. Zhu AX, Meyerhardt JA, Blaszkowsky LS, Kambadakone AR, Muzikansky A, Zheng H, Clark JW, Abrams TA, Chan JA, Enzinger PC, Bhargava P, Kwak EL, Allen JN, Jain SR, Stuart K, Horgan K, et al. Efficacy and safety of gemcitabine, oxaliplatin, and bevacizumab in advanced biliary-tract cancers and correlation of changes in 18-fluorodeoxyglucose PET with clinical outcome: a phase 2 study. Lancet Oncol. 2010; 11:48-54.

40. Lubner SJ, Mahoney MR, Kolesar JL, Loconte NK, Kim GP, Pitot HC, Philip PA, Picus J, Yong WP, Horvath L, Van Hazel G, Erlichman CE and Holen KD. Report of a multicenter phase II trial testing a combination of biweekly bevacizumab and daily erlotinib in patients with unresectable biliary cancer: a phase II Consortium study. J Clin Oncol. 2010; 28:3491-3497.

41. Iyer RV, Iyer AG, Ma WW, Malhotra U, Iancu D, Grande C, Bekaii-Saab TS. Gemcitabine (G), capecitabine (C) and bevacizumab $(\mathrm{BV})$ in patients with advanced biliary cancers $(\mathrm{ABC})$ : final results of a multicenter phase II study. J Clin Oncol. 2015; 33 (suppl; abstr 4078).

42. El-Khoueiry AB, Rankin C, Siegel AB, Iqbal S, Gong IY, Micetich KC, Kayaleh OR, Lenz HJ and Blanke CD. S0941: a phase 2 SWOG study of sorafenib and erlotinib in patients with advanced gallbladder carcinoma or cholangiocarcinoma. Br J Cancer. 2014; 110:882-887.

43. El-Khoueiry AB, Rankin CJ, Ben-Josef E, Lenz HJ, Gold PJ, Hamilton RD, Govindarajan R, Eng C and Blanke CD. SWOG 0514: a phase II study of sorafenib in patients with unresectable or metastatic gallbladder carcinoma and cholangiocarcinoma. Invest New Drugs. 2012; 30:16461651 .

44. Moehler M, Maderer A, Schimanski C, Kanzler S, Denzer U, Kolligs FT, Ebert MP, Distelrath A, Geissler M, Trojan J, Schutz M, Berie L, Sauvigny C, Lammert F, Lohse A, Dollinger MM, et al. Gemcitabine plus sorafenib versus gemcitabine alone in advanced biliary tract cancer: a double-blind placebo-controlled multicentre phase II AIO study with biomarker and serum programme. Eur J Cancer. 2014; 50:3125-3135.

45. Bengala C, Bertolini F, Malavasi N, Boni C, Aitini E, Dealis C, Zironi S, Depenni R, Fontana A, Del Giovane C, Luppi $\mathrm{G}$ and Conte P. Sorafenib in patients with advanced biliary tract carcinoma: a phase II trial. Br J Cancer. 2010; 102:68-72.

46. Lee JK, Capanu M, O’Reilly EM, Ma J, Chou JF, Shia J, Katz SS, Gansukh B, Reidy-Lagunes D, Segal NH, Yu KH, Chung KY, Saltz LB and Abou-Alfa GK. A phase II study of gemcitabine and cisplatin plus sorafenib in patients with advanced biliary adenocarcinomas. Br J Cancer. 2013; 109:915-919.

47. Yi JH, Thongprasert S, Lee J, Doval DC, Park SH, Park JO, Park YS, Kang WK and Lim HY. A phase II study of sunitinib as a second-line treatment in advanced biliary tract carcinoma: a multicentre, multinational study. Eur J Cancer. 2012; 48:196-201.

48. Santoro A, Gebbia V, Pressiani T, Testa A, Personeni N, Arrivas Bajardi E, Foa P, Buonadonna A, Bencardino K, Barone C, Ferrari D, Zaniboni A, Tronconi MC, Carteni G, Milella M, Comandone A, et al. A randomized, multicenter, phase II study of vandetanib monotherapy versus vandetanib in combination with gemcitabine versus gemcitabine plus placebo in subjects with advanced biliary tract cancer: the VanGogh study. Ann Oncol. 2015; 26:542547.

49. Valle JW, Wasan H, Lopes A, Backen AC, Palmer DH, Morris K, Duggan M, Cunningham D, Anthoney DA, Corrie P, Madhusudan S, Maraveyas A, Ross PJ, Waters JS, Steward WP, Rees C, et al. Cediranib or placebo in combination with cisplatin and gemcitabine chemotherapy for patients with advanced biliary tract cancer (ABC-03): a randomised phase 2 trial. Lancet Oncol. 2015; 16:967-978.

50. Gherardi E, Birchmeier W, Birchmeier C and Vande Woude G. Targeting MET in cancer: rationale and progress. Nat Rev Cancer. 2012; 12:89-103.

51. Marquardt JU and Andersen JB. Next-generation sequencing: application in liver cancer-past, present and future? Biology (Basel). 2012; 1:383-394.

52. Pant S, Saleh M, Bendell J, Infante JR, Jones S, Kurkjian CD, Moore KM, Kazakin J, Abbadessa G, Wang Y, Chen Y, Schwartz B and Camacho LH. A phase I dose escalation study of oral c-MET inhibitor tivantinib (ARQ 197) in combination with gemcitabine in patients with solid tumors. Ann Oncol. 2014; 25:1416-1421.

53. Lipika Goyal MBY, Abrams TA, Kwak EL, Cleary JM, Knowles M, Regan E, Gisondi A, Sheehan S, Zheng H, Zhu AX. A phase II trial of cabozantinib (XL-184) in patients with advanced cholangiocarcinoma. J Clin Oncol. 2015; 33 (suppl 3; abstr 800).

54. Goyal L, Govindan A, Sheth RA, Nardi V, Blaszkowsky LS, Faris JE, Clark JW, Ryan DP, Kwak EL, Allen JN, Murphy JE, Saha SK, Hong TS, Wo JY, Ferrone CR, 
Tanabe KK, et al. Prognosis and Clinicopathologic Features of Patients With Advanced Stage Isocitrate Dehydrogenase (IDH) Mutant and IDH Wild-Type Intrahepatic Cholangiocarcinoma. Oncologist. 2015; 20:1019-1027.

55. Grassian AR, Pagliarini R and Chiang DY. Mutations of isocitrate dehydrogenase 1 and 2 in intrahepatic cholangiocarcinoma. Curr Opin Gastroenterol. 2014; 30:295-302.

56. Rohle D, Popovici-Muller J, Palaskas N, Turcan S, Grommes C, Campos C, Tsoi J, Clark O, Oldrini B, Komisopoulou E, Kunii K, Pedraza A, Schalm S, Silverman L, Miller A, Wang F, et al. An inhibitor of mutant IDH1 delays growth and promotes differentiation of glioma cells. Science. 2013; 340:626-630.

57. Wang F, Travins J, DeLaBarre B, Penard-Lacronique V, Schalm S, Hansen E, Straley K, Kernytsky A, Liu W, Gliser C, Yang H, Gross S, Artin E, Saada V, Mylonas E, Quivoron C, et al. Targeted inhibition of mutant IDH2 in leukemia cells induces cellular differentiation. Science. 2013; 340:622-626.

58. Tiong KH, Mah LY and Leong CO. Functional roles of fibroblast growth factor receptors (FGFRs) signaling in human cancers. Apoptosis. 2013; 18:1447-1468.

59. Wu YM, Su F, Kalyana-Sundaram S, Khazanov N, Ateeq B, Cao X, Lonigro RJ, Vats P, Wang R, Lin SF, Cheng AJ, Kunju LP, Siddiqui J, Tomlins SA, Wyngaard P, Sadis S, et al. Identification of targetable FGFR gene fusions in diverse cancers. Cancer Discov. 2013; 3:636-647.

60. Nakamura H, Arai Y, Totoki Y, Shirota T, Elzawahry A, Kato M, Hama N, Hosoda F, Urushidate T, Ohashi S, Hiraoka N, Ojima H, Shimada K, Okusaka T, Kosuge T, Miyagawa S, et al. Genomic spectra of biliary tract cancer. Nat Genet. 2015; 47:1003-1010.

61. Takahashi R, Yoshitomi M, Yutani S, Shirahama T, Noguchi M, Yamada A, Itoh K and Sasada T. Current status of immunotherapy for the treatment of biliary tract cancer. Hum Vaccin Immunother. 2013; 9:1069-1072.

62. Oshikiri T, Miyamoto M, Shichinohe T, Suzuoki M, Hiraoka K, Nakakubo Y, Shinohara T, Itoh T, Kondo S and Katoh H. Prognostic value of intratumoral CD8+ T lymphocyte in extrahepatic bile duct carcinoma as essential immune response. J Surg Oncol. 2003; 84:224-228.

63. Lipson EJ and Drake CG. Ipilimumab: an anti-CTLA-4 antibody for metastatic melanoma. Clin Cancer Res. 2011; 17:6958-6962.

64. Sullivan RJ and Flaherty KT. Pembrolizumab for Treatment of Patients with Advanced or Unresectable Melanoma. Clin Cancer Res. 2015; 21:2892-2897.

65. Koido S, Kan S, Yoshida K, Yoshizaki S, Takakura K, Namiki Y, Tsukinaga S, Odahara S, Kajihara M, Okamoto M, Ito M, Yusa S, Gong J, Sugiyama H, Ohkusa T, Homma $\mathrm{S}$, et al. Immunogenic modulation of cholangiocarcinoma cells by chemoimmunotherapy. Anticancer Res. 2014; 34:6353-6361.
66. Le DT, Uram JN, Wang H, Bartlett BR, Kemberling $\mathrm{H}$, Eyring AD, Skora AD, Luber BS, Azad NS, Laheru D, Biedrzycki B, Donehower RC, Zaheer A, Fisher GA, Crocenzi TS, Lee JJ, et al. PD-1 Blockade in Tumors with Mismatch-Repair Deficiency. N Engl J Med. 2015; 372:2509-2520.

67. Saborowski A, Saborowski M, Davare MA, Druker BJ, Klimstra DS and Lowe SW. Mouse model of intrahepatic cholangiocarcinoma validates FIG-ROS as a potent fusion oncogene and therapeutic target. Proc Natl Acad Sci U S A. 2013; 110:19513-19518.

68. Solomon BJ, Mok T, Kim DW, Wu YL, Nakagawa K, Mekhail T, Felip E, Cappuzzo F, Paolini J, Usari T, Iyer S, Reisman A, Wilner KD, Tursi J, Blackhall $\mathrm{F}$ and Investigators P. First-line crizotinib versus chemotherapy in ALK-positive lung cancer. N Engl J Med. 2014; 371:21672177.

69. Andersen JB, Spee B, Blechacz BR, Avital I, Komuta M, Barbour A, Conner EA, Gillen MC, Roskams T, Roberts LR, Factor VM and Thorgeirsson SS. Genomic and genetic characterization of cholangiocarcinoma identifies therapeutic targets for tyrosine kinase inhibitors. Gastroenterology. 2012; 142:1021-1031 e1015.

70. Voss JS, Holtegaard LM, Kerr SE, Fritcher EG, Roberts LR, Gores GJ, Zhang J, Highsmith WE, Halling KC and Kipp BR. Molecular profiling of cholangiocarcinoma shows potential for targeted therapy treatment decisions. Hum Pathol. 2013; 44:1216-1222.

71. Xu RF, Sun JP, Zhang SR, Zhu GS, Li LB, Liao YL, Xie JM and Liao WJ. KRAS and PIK3CA but not BRAF genes are frequently mutated in Chinese cholangiocarcinoma patients. Biomed Pharmacother. 2011; 65:22-26.

72. Lee D, Do IG, Choi K, Sung CO, Jang KT, Choi D, Heo JS, Choi SH, Kim J, Park JY, Cha HJ, Joh JW, Choi KY and Kim DS. The expression of phospho-AKT1 and phosphoMTOR is associated with a favorable prognosis independent of PTEN expression in intrahepatic cholangiocarcinomas. Mod Pathol. 2012; 25:131-139.

73. Ewald F, Norz D, Grottke A, Hofmann BT, Nashan B and Jucker M. Dual Inhibition of PI3K-AKT-mTOR- and RAFMEK-ERK-signaling is synergistic in cholangiocarcinoma and reverses acquired resistance to MEK-inhibitors. Invest New Drugs. 2014; 32:1144-1154.

74. Ewald F, Grabinski N, Grottke A, Windhorst S, Norz D, Carstensen L, Staufer K, Hofmann BT, Diehl F, David K, Schumacher U, Nashan B and Jucker M. Combined targeting of AKT and mTOR using MK-2206 and RAD001 is synergistic in the treatment of cholangiocarcinoma. Int $\mathrm{J}$ Cancer. 2013; 133:2065-2076.

75. McRee AJ, Sanoff HK, Carlson C, Ivanova A and O'Neil $\mathrm{BH}$. A phase I trial of mFOLFOX6 combined with the oral PI3K inhibitor BKM120 in patients with advanced refractory solid tumors. Invest New Drugs. 2015; 33:12251231. 
76. Costello BA, Borad MJ, Qi Y, Kim GP, Northfelt DW, Erlichman $\mathrm{C}$ and Alberts SR. Phase I trial of everolimus, gemcitabine and cisplatin in patients with solid tumors. Invest New Drugs. 2014; 32:710-716.

77. O'Neill E and Kolch W. Conferring specificity on the ubiquitous Raf/MEK signalling pathway. Br J Cancer. 2004; 90:283-288.

78. Chen TC, Jan YY and Yeh TS. K-ras mutation is strongly associated with perineural invasion and represents an independent prognostic factor of intrahepatic cholangiocarcinoma after hepatectomy. Ann Surg Oncol. 2012; 19 Suppl 3:S675-681.

79. Robertson S, Hyder O, Dodson R, Nayar SK, Poling J, Beierl K, Eshleman JR, Lin MT, Pawlik TM and Anders RA. The frequency of KRAS and BRAF mutations in intrahepatic cholangiocarcinomas and their correlation with clinical outcome. Hum Pathol. 2013; 44:2768-2773.

80. Bekaii-Saab T, Phelps MA, Li X, Saji M, Goff L, Kauh JS, O’Neil BH, Balsom S, Balint C, Liersemann R, Vasko VV, Bloomston M, Marsh W, Doyle LA, Ellison G, Grever M, et al. Multi-institutional phase II study of selumetinib in patients with metastatic biliary cancers. J Clin Oncol. 2011; 29:2357-2363.

81. Bridgewater J, Lopes A, Beare S, Duggan M, Lee D, Ricamara M, McEntee D, Sukumaran A, Wasan H and Valle JW. A phase 1b study of Selumetinib in combination with Cisplatin and Gemcitabine in advanced or metastatic biliary tract cancer: the ABC-04 study. BMC Cancer. 2016; 16:153.

82. Tannapfel A, Sommerer F, Benicke M, Katalinic A, Uhlmann D, Witzigmann H, Hauss J and Wittekind C. Mutations of the BRAF gene in cholangiocarcinoma but not in hepatocellular carcinoma. Gut. 2003; 52:706-712.

83. Hyman DM, Puzanov I, Subbiah V, Faris JE, Chau I, Blay JY, Wolf J, Raje NS, Diamond EL, Hollebecque A, Gervais R, Elez-Fernandez ME, Italiano A, Hofheinz RD, Hidalgo M, Chan E, et al. Vemurafenib in Multiple Nonmelanoma Cancers with BRAF V600 Mutations. N Engl J Med. 2015; 373:726-736.

84. Shen DY, Zhang W, Zeng X and Liu CQ. Inhibition of Wnt/beta-catenin signaling downregulates P-glycoprotein and reverses multi-drug resistance of cholangiocarcinoma. Cancer Sci. 2013; 104:1303-1308.

85. Denlinger CS, Meropol NJ, Li T, Lewis NL, Engstrom PF, Weiner LM, Cheng JD, Alpaugh RK, Cooper H, Wright JJ and Cohen SJ. A phase II trial of the proteasome inhibitor bortezomib in patients with advanced biliary tract cancers. Clin Colorectal Cancer. 2014; 13:81-86.

86. Sia D, Tovar V, Moeini A and Llovet JM. Intrahepatic cholangiocarcinoma: pathogenesis and rationale for molecular therapies. Oncogene. 2013; 32:4861-4870.

87. Sia D, Hoshida Y, Villanueva A, Roayaie S, Ferrer J, Tabak B, Peix J, Sole M, Tovar V, Alsinet C, Cornella
H, Klotzle B, Fan JB, Cotsoglou C, Thung SN, Fuster $\mathrm{J}$, et al. Integrative molecular analysis of intrahepatic cholangiocarcinoma reveals 2 classes that have different outcomes. Gastroenterology. 2013; 144:829-840.

88. Hedvat M, Huszar D, Herrmann A, Gozgit JM, Schroeder A, Sheehy A, Buettner R, Proia D, Kowolik CM, Xin $\mathrm{H}$, Armstrong B, Bebernitz G, Weng S, Wang L, Ye M, McEachern K, et al. The JAK2 inhibitor AZD1480 potently blocks Stat 3 signaling and oncogenesis in solid tumors. Cancer Cell. 2009; 16:487-497.

89. Zender S, Nickeleit I, Wuestefeld T, Sorensen I, Dauch D, Bozko P, El-Khatib M, Geffers R, Bektas H, Manns MP, Gossler A, Wilkens L, Plentz R, Zender L and Malek NP. A critical role for notch signaling in the formation of cholangiocellular carcinomas. Cancer Cell. 2013; 23:784795.

90. El Khatib M, Bozko P, Palagani V, Malek NP, Wilkens L and Plentz RR. Activation of Notch signaling is required for cholangiocarcinoma progression and is enhanced by inactivation of p53 in vivo. PLoS One. 2013; 8:e77433.

91. Sekiya S and Suzuki A. Intrahepatic cholangiocarcinoma can arise from Notch-mediated conversion of hepatocytes. J Clin Invest. 2012; 122:3914-3918.

92. Wu WR, Zhang R, Shi XD, Zhu MS, Xu LB, Zeng H and Liu C. Notch1 is overexpressed in human intrahepatic cholangiocarcinoma and is associated with its proliferation, invasiveness and sensitivity to 5-fluorouracil in vivo. Oncol Rep. 2014; 31:2515-2524.

93. Loilome W, Juntana S, Namwat N, Bhudhisawasdi V, Puapairoj A, Sripa B, Miwa M, Saya H, Riggins GJ and Yongvanit P. PRKAR1A is overexpressed and represents a possible therapeutic target in human cholangiocarcinoma. Int J Cancer. 2011; 129:34-44.

94. Reya $\mathrm{T}$ and Clevers $\mathrm{H}$. Wnt signalling in stem cells and cancer. Nature. 2005; 434:843-850.

95. Boulter L, Guest RV, Kendall TJ, Wilson DH, Wojtacha D, Robson AJ, Ridgway RA, Samuel K, Van Rooijen N, Barry ST, Wigmore SJ, Sansom OJ and Forbes SJ. WNT signaling drives cholangiocarcinoma growth and can be pharmacologically inhibited. J Clin Invest. 2015; 125:12691285.

96. Huang GL, Shen DY, Cai CF, Zhang QY, Ren HY and Chen QX. beta-escin reverses multidrug resistance through inhibition of the GSK3beta/beta-catenin pathway in cholangiocarcinoma. World J Gastroenterol. 2015; 21:11481157.

97. Philip PA, Mahoney MR, Allmer C, Thomas J, Pitot HC, Kim G, Donehower RC, Fitch T, Picus J and Erlichman C. Phase II study of erlotinib in patients with advanced biliary cancer. J Clin Oncol. 2006; 24:3069-3074.

98. Gruenberger B, Schueller J, Heubrandtner U, Wrba F, Tamandl D, Kaczirek K, Roka R, Freimann-Pircher S and Gruenberger T. Cetuximab, gemcitabine, and oxaliplatin in 
patients with unresectable advanced or metastatic biliary tract cancer: a phase 2 study. Lancet Oncol. 2010; 11:11421148.

99. Paule B, Herelle MO, Rage E, Ducreux M, Adam R, Guettier C and Bralet MP. Cetuximab plus gemcitabineoxaliplatin (GEMOX) in patients with refractory advanced intrahepatic cholangiocarcinomas. Oncology. 2007; 72(12):105-110.

100. Rubovszky G, Lang I, Ganofszky E, Horvath Z, Juhos E, Nagy T, Szabo E, Szentirmay Z, Budai B and Hitre E. Cetuximab, gemcitabine and capecitabine in patients with inoperable biliary tract cancer: a phase 2 study. Eur J Cancer. 2013; 49:3806-3812.

101. Borbath I, Ceratti A, Verslype C, Demols A, Delaunoit T, Laurent S, Deleporte A, Vergauwe P, Van Maanen A, Sempoux C, Van Cutsem E, Van Laethem JL and Belgian Group of Digestive O. Combination of gemcitabine and cetuximab in patients with advanced cholangiocarcinoma: a phase II study of the Belgian Group of Digestive Oncology. Ann Oncol. 2013; 24:2824-2829.

102. Jensen LH, Lindebjerg J, Ploen J, Hansen TF and Jakobsen A. Phase II marker-driven trial of panitumumab and chemotherapy in KRAS wild-type biliary tract cancer. Ann Oncol. 2012; 23:2341-2346.
103. Hezel AF, Noel MS, Allen JN, Abrams TA, Yurgelun M, Faris JE, Goyal L, Clark JW, Blaszkowsky LS, Murphy JE, Zheng H, Khorana AA, Connolly GC, Hyrien O, Baran A, Herr M, et al. Phase II study of gemcitabine, oxaliplatin in combination with panitumumab in KRAS wild-type unresectable or metastatic biliary tract and gallbladder cancer. Br J Cancer. 2014; 111:430-436.

104. Sohal DP, Mykulowycz K, Uehara T, Teitelbaum UR, Damjanov N, Giantonio BJ, Carberry M, Wissel P, JacobsSmall M, O’Dwyer PJ, Sepulveda A and Sun W. A phase II trial of gemcitabine, irinotecan and panitumumab in advanced cholangiocarcinoma. Ann Oncol. 2013; 24:30613065.

105. Ramanathan RK, Belani CP, Singh DA, Tanaka M, Lenz HJ, Yen Y, Kindler HL, Iqbal S, Longmate J, Mack PC, Lurje G, Gandour-Edwards R, Dancey J and Gandara DR. A phase II study of lapatinib in patients with advanced biliary tree and hepatocellular cancer. Cancer Chemother Pharmacol. 2009; 64:777-783. 